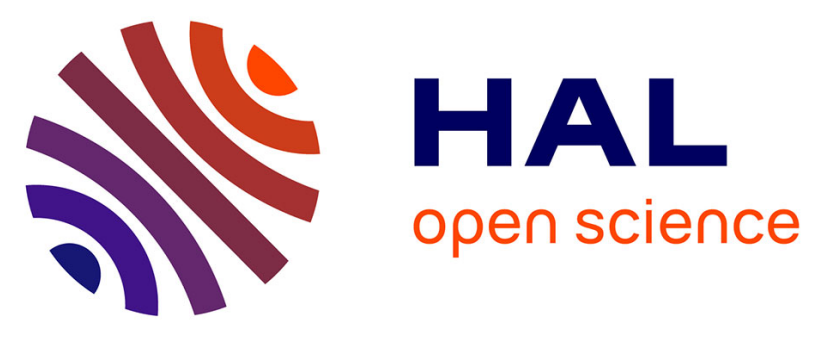

\title{
Block Tectonics Across Western Tibet and Multi-Millennial Recurrence of Great Earthquakes on the Karakax Fault
}

H. Li, M. Chevalier, P. Tapponnier, J. Pan, Jerome van Der Woerd, A. Mériaux, F. Ryerson, G. Peltzer, Z. Sun, J. Si, et al.

\section{To cite this version:}

H. Li, M. Chevalier, P. Tapponnier, J. Pan, Jerome van Der Woerd, et al.. Block Tectonics Across Western Tibet and Multi-Millennial Recurrence of Great Earthquakes on the Karakax Fault. Journal of Geophysical Research: Solid Earth, 2021, 126 (12), pp.e2021JB022033. 10.1029/2021JB022033 . hal-03517823

\section{HAL Id: hal-03517823 \\ https://hal.science/hal-03517823}

Submitted on 12 Jan 2022

HAL is a multi-disciplinary open access archive for the deposit and dissemination of scientific research documents, whether they are published or not. The documents may come from teaching and research institutions in France or abroad, or from public or private research centers.
L'archive ouverte pluridisciplinaire HAL, est destinée au dépôt et à la diffusion de documents scientifiques de niveau recherche, publiés ou non, émanant des établissements d'enseignement et de recherche français ou étrangers, des laboratoires publics ou privés. 
Block Tectonics across Western Tibet and Multi-Millennial Recurrence of Great

Earthquakes on the Karakax Fault

4 H. Li ${ }^{1,2^{*}}$, M.L. Chevalier ${ }^{1,2}$, P. Tapponnier ${ }^{3,2}$, J. Pan ${ }^{1,2}$, J. Van der Woerd ${ }^{4}$, A.S. Mériaux ${ }^{4}$,

$7 \quad{ }^{1}$ Key Laboratory of Deep-Earth Dynamics of Ministry of Natural Resources, Institute of

8 Geology, Chinese Academy of Geological Sciences, Beijing, China

$9{ }^{2}$ Southern Marine Science and Engineering Guangdong Laboratory (Guangzhou), Guangzhou, 10 China

$11{ }^{3}$ National Institute of Natural Hazards, Ministry of Emergency Management of China, Beijing,

12 China

$13{ }^{4}$ Institut Terre et Environnement de Strasbourg, Strasbourg, France

$14{ }^{5}$ Lawrence Livermore National Laboratory, Livermore, California, USA

$15{ }^{6}$ University of California Los Angeles, Los Angeles, CA95095, USA

$16{ }^{7}$ Jet Propulsion Laboratory, California Institute of Technology, CA, USA

$17{ }^{8}$ Institute of Geomechanics, Chinese Academy of Geological Sciences, Beijing, China

19 Corresponding author: Haibing Li (lihaibing06@163.com)

21 Key Points:

- The $\sim 400 \mathrm{~km}$-long, left-lateral Karakax fault (western Altyn Tagh fault) slip rate has been $\sim 2.5 \pm 0.5 \mathrm{~mm} / \mathrm{yr}$ for $\sim 210 \mathrm{ka}$

- Four M 7.6 earthquakes (150 km rupture length; $2.5 \mathrm{ka}$ return time) have offset 
- Block tectonics and triple junction kinematics account for 24 Ma deformation of west Tibet and rise of $\geq 8000$ m-high Karakorum range 
Fault slip rates are critical to quantify continental deformation. Those along the Karakax

31 fault (northwestern Altyn Tagh Fault: ATF) have been debated, even though it is one of Tibet's

32 most outstanding active faults. At Taersa, using LiDAR measurements of terrace and fan riser

33 offsets ( $\sim 6$ to $\sim 500 \mathrm{~m})$ and ${ }^{10} \mathrm{Be} /{ }^{26} \mathrm{Al}$ dating of alluvial surfaces $(<210 \mathrm{ka})$, we obtain a late

34 Quaternary slip rate of $\sim 2.5 \pm 0.5 \mathrm{~mm} / \mathrm{yr}$. This doubles the $\sim 2.6 \pm 0.5 \mathrm{~mm} / \mathrm{yr}$ rate time span found

35 to the east and west. We interpret the $\sim 150 \mathrm{~km}$-long, free-faced rupture along the fault to be that

36 of the M 7.6 event felt in Hotan in 1882. Characteristic slip ( $\sim 6 \mathrm{~m})$ during four large

37 earthquakes since $\sim 10 \mathrm{ka}$ implies a $\sim 2500 \pm 500$ yrs return time. A $\sim 3 \mathrm{~mm} / \mathrm{yr}$ rate is consistent

38 with the $\sim 80 \mathrm{~km}$ offset of the Karakax river since uplift of the West Kunlun range and sediment

39 deposition in the Tarim foreland accelerated, $\sim 24 \mathrm{Ma}$ ago. The faster slip rate $(\sim 10.5 \mathrm{~mm} / \mathrm{yr})$ on

40 the central ATF matches the sum of those along the reactivated West Tibetan terrane boundaries

41 (Karakax and Longmu-Gozha Co faults) at the Uzatagh triple junction $\left(\sim 36^{\circ} \mathrm{N}\right.$,

$\left.4283^{\circ} \mathrm{E}\right)$. The abrupt termination and altitude drop of the Karakorum range where the Longmu Co

43 and Karakorum faults meet (Angmong junction), also reflect triple junction kinematics. Such

44 localized changes account for the rise of the Karakorum and West Kunlun ranges and support

45 lithospheric block tectonics rather than diffusely distributed deformation.

47 Plain Language Summary

How the Tibetan plateau rose to $\sim 4500 \mathrm{~m}$ and deforms today remain outstanding

49 questions. Tibet's northern edge follows the $\sim 2000 \mathrm{~km}$-long Altyn Tagh fault, whose

50 westernmost branch is the Karakax fault. Despite the spectacular escarpments and offsets 
51 observed along that fault, its slip rate, critical to quantify continental deformation, has remained

52 controversial. Here, we corroborate that, for the last $\sim 210,000$ yrs, that rate has been $\sim 2.5 \pm 0.5$

$53 \mathrm{~mm} / \mathrm{yr}$, based on high-resolution topography and dating of left-laterally offset fluvial surfaces.

54 The $\sim 80 \mathrm{~km}$ offset of the Karakax river implies that this rate may have remained constant since

55 the rise of the Kunlun range above the Tarim basin started 24 Ma ago. The sharp fault trace

56 reflects the exceptional preservation, since $\sim 10,000$ years ago, of four $\mathrm{M} \sim 7.6$ earthquake ruptures

57 (the last in 1882), each with $\sim 6 \mathrm{~m}$ of slip ( $\sim 2500$ yrs return time). Fault slip rates, GPS vectors

58 and mountain altitudes across western Tibet reflect block motions and triple junction kinematics

59 rather than continuum deformation. Specifically, localized velocity changes appear to account

60 for the rise of the West Kunlun and Karakorum ranges. Our results bridge the gaps between

61 present and long-term geological history, and broad-scale geodesy and local field evidence.

\section{Introduction}

The accurate determination of fault slip rates at various timescales is key to quantifying continental deformation kinematics, long-term seismicity and lithospheric rheology. Yet, because

66 fault offsets and marker ages derived from different measurements and dating techniques are

67 often difficult to constrain beyond doubt or to interpret jointly, and because slip-rates can be

68 time-dependent (e.g., Chevalier et al., 2005), conflicting long-term slip rate values have been

69 proposed along even the best studied active faults. In western Tibet, the longest segment of the

$70 \sim 400 \mathrm{~km}-$ long, $\sim 100^{\circ}$ E-striking Karakax fault (KXF), northwestern branch of the $\sim 2000 \mathrm{~km}-1 \mathrm{ong}$,

71 left-lateral Altyn Tagh fault (ATF), is partly confined along the $\sim 3-4 \mathrm{~km}$-wide Karakax river

72 valley. It follows the southern edge of the West Kunlun range, along the northern boundary of

73 the Tianshuihai terrane (Fig. 1). Together with the sinistral Longmu-Gozha Co and dextral 
74 Karakorum faults farther south, it contributes to absorb the convergence between India and Asia, 75 and to steer the eastward extrusion of Tibet (e.g., Tapponnier and Molnar, 1977; Armijo et al.,

76 1989; Avouac and Tapponnier, 1993; Tapponnier et al., 2001; Chevalier et al., 2017). Due to

77 access restrictions and a remote location at $\sim 3700 \mathrm{~m}$, the KXF has been the target of few field

78 studies (e.g., Matte et al., 1996; Li et al., 2012; Gong et al., 2017; Peltzer et al., 2020), in spite of

79 spectacular, long-identified geomorphic markers (pull-apart basins, pressure ridges, and offset

80 streams, terraces, fans and moraines) (Peltzer et al., 1989). 

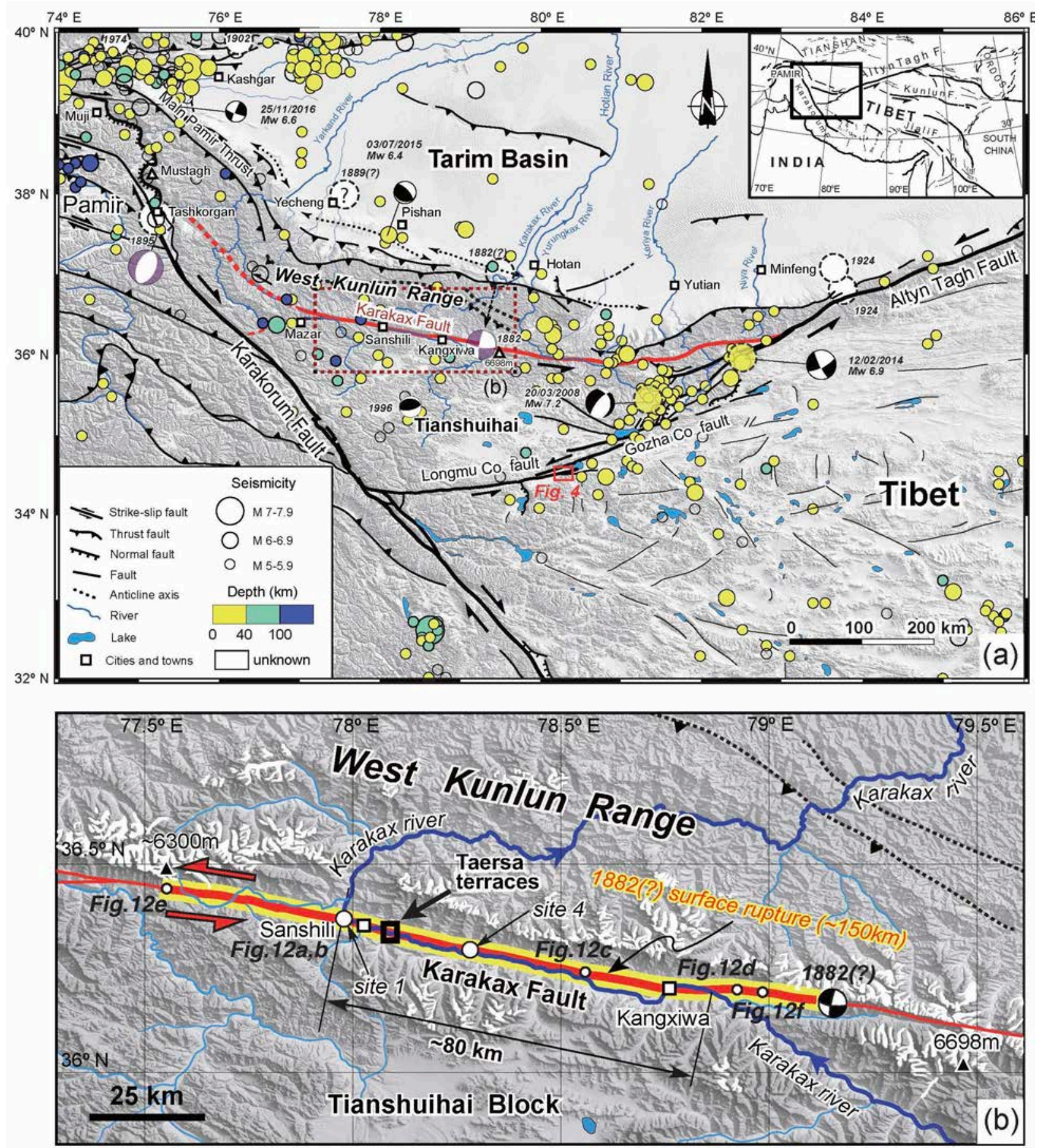

82 Figure 1. Active faulting in the Altyn Tagh - Karakorum junction area. (a) Simplified map of

83 Quaternary faults across western Tibet and Tarim (Karakax fault in red). Inset shows location

84 within India-Asia collision zone. Circles are epicenters of $M \geq 5$ earthquakes since 1976 (SBX,

85 1997; USGS), colored as a function of depth. Dashed large white circles are reported or inferred

86 locations of older historical earthquakes. Black/white fault plane solutions are for $M \geq 6.4$ 
earthquakes recorded by www.globalcmt.org, while two light-purple/white ones are those of the 1882 and 1895 historical events, consistent with surface rupture observations (Liu, 1993). (b) Close-up of left-lateral Karakax fault main trace. Black square is location of Taersa terraces site. Thick yellow/red line shows $\sim 150 \mathrm{~km}$ length of inferred sinistral surface rupture of 1882 earthquake (black white focal mechanism). Note $\sim 80 \mathrm{~km}$ sinistral offset of Karakax river. Large white circles are Sites 1 and 4 from Peltzer et al. (2020) and small white circles refer to surface rupture field photographs and satellite images shown in Figure 12.

Pioneering observations with Landsat images demonstrated that the KXF is an active leftlateral strike-slip fault (Tapponnier and Molnar, 1977). The subsequent use of $10 \mathrm{~m}$-resolution

97 Spot images provided the first measurements of syn- or post-glacial offsets of up to $250 \mathrm{~m}$ (Peltzer et al., 1989). This initially suggested an inferred Holocene slip rate as large as $\sim 20-24$ $\mathrm{mm} / \mathrm{yr}$, in keeping with the youthful geomorphic trace of the fault. Such a fast rate similar to that along California's San Andreas fault and compatible with that formerly inferred along the central

101 ATF ( 30 mm/yr, e.g., Molnar et al., 1987; Armijo et al., 1989; Molnar and Lyon-Caen, 1989)

102 was long deemed plausible (e.g., Avouac and Peltzer, 1993; Avouac and Tapponnier, 1993). This

103 was also consistent with a convergence rate between India and Asia formerly estimated to be as

104 large as $\sim 5 \mathrm{~cm} / \mathrm{yr}$ based on Nuvel 1 and plate tectonic reconstructions (DeMets et al., 1990).

105 Later on, quantitative field measurements and sampling suggested a slip rate bracket of 12-25

$106 \mathrm{~mm} / \mathrm{yr}$ in the last $\sim 15 \mathrm{ka}$ (Ryerson et al., 1999; dataset published in Peltzer et al., 2020). Much

107 slower slip rates, however, have been proposed in recent years. Li et al. (2012) suggested $\sim 6-7$

$108 \mathrm{~mm} / \mathrm{yr}$ during the last $\sim 1000$ years, based on one ${ }^{14} \mathrm{C}$ age in a trench $\sim 2 \mathrm{~km}$ east of Sanshili (Fig.

109 2). At the location of our present study, from Optically Stimulated Luminescence (OSL) dating 110 of fluvial sand samples from offset river terraces, Gong et al. (2017) obtained a similar rate of $1117.8 \pm 1.6 \mathrm{~mm} / \mathrm{yr}$ during the last $\sim 40 \mathrm{ka}$. Yet more recently, Peltzer et al. (2020) obtained an even 
112 slower rate of $2.6 \pm 0.5 \mathrm{~mm} / \mathrm{yr}$ since $\sim 115 \mathrm{ka}$, by combining diffusion modeling of fault scarps,

$1133 \mathrm{D}$ fan offset reconstructions, and $\mathrm{OSL} /{ }^{10} \mathrm{Be}$ dating of offset terraces at two sites $\sim 35 \mathrm{~km}$ apart

114 (Fig. 1b).

115 Here, based on Light Detection And Ranging (LiDAR) geomorphic measurements and

$116{ }^{10} \mathrm{Be} /{ }^{26} \mathrm{Al}$ cosmogenic surface-exposure and depth profile dating at Taersa, $5 \mathrm{~km}$ east of Sanshili,

117 we further assess plausible values of the KXF slip rate in the last $210 \mathrm{ka}$ and infer the return

118 times of four Holocene great earthquakes on the fault. This is possible because of the outstanding

119 preservation of superficial morphology due to a particularly arid climate $(36 \mathrm{~mm} / \mathrm{yr}$ of annual

120 precipitation in Kangxiwa, Yao et al., 1996). We also re-assess the $\sim 150$ ka slip rate along the

121 Longmu Co fault, $\sim 250 \mathrm{~km} \mathrm{SE}$ of the Karakax valley, and examine how such large faults control

122 the large-scale kinematics of block deformation across western Tibet.

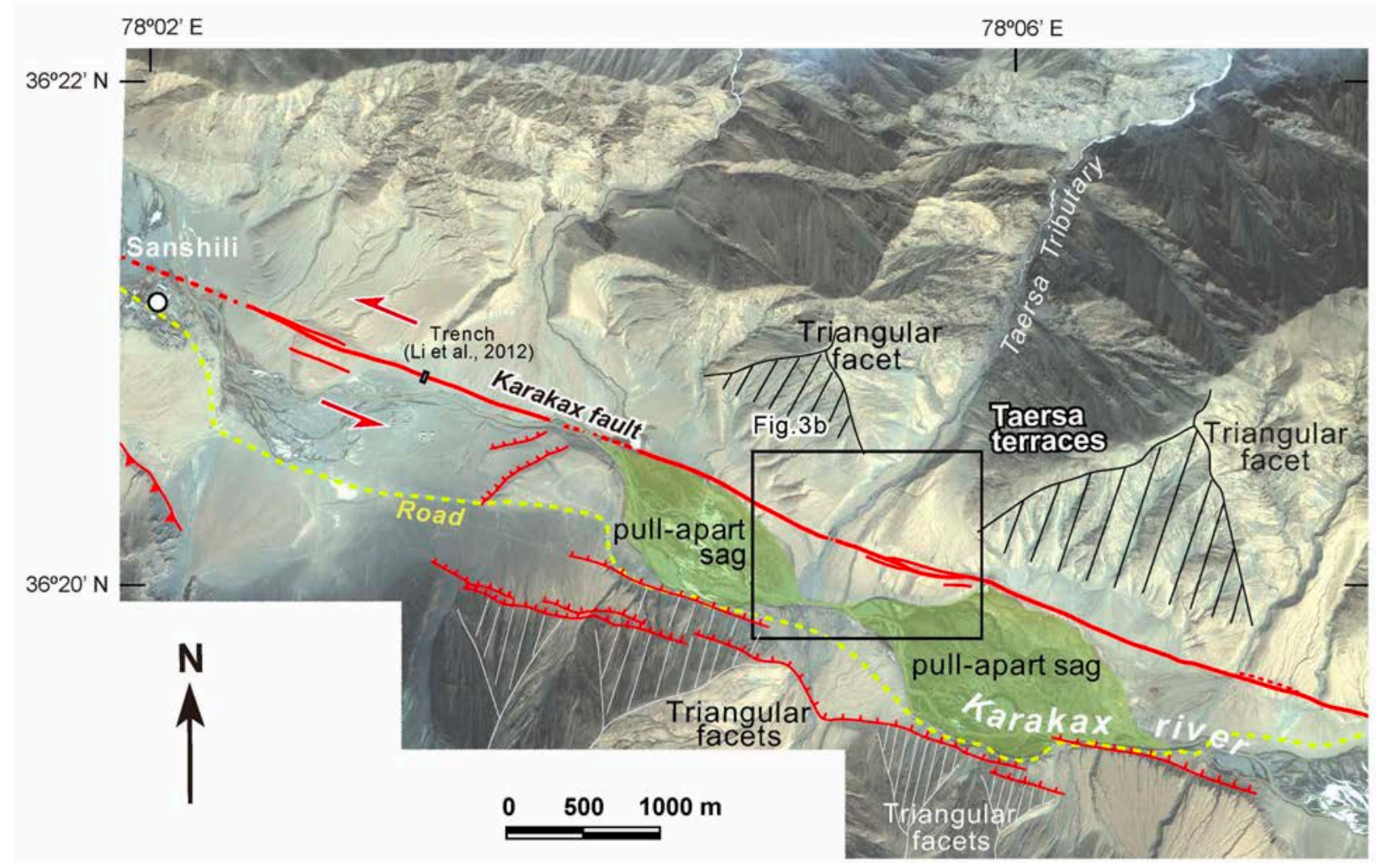

124 Figure 2. Map of main active strands of Karakax fault system around Taersa site, based on 125 Ikonos image and field mapping of recent surface traces (red) across Karakax valley near 
Sanshili. The Taersa tributary flows south into a deep, swampy pull-apart sag (green shade) along the river valley, abandoning uplifted fans and terraces across the fault. Recent, northfacing and NE-striking normal fault scarps (red lines with tick bars) also cut fluvial fans south of the river. Triangular facets attesting to components of normal faulting south and north of the river are also indicated. Black rectangle shows location of trench site from Li et al. (2012).

\section{Methods}

Meltwaters from the West Kunlun range glaciers flow into the $\sim$ EW-trending Karakax river valley (Fig. 2), depositing large fans and terraces (Fig. 3). The Karakax strike-slip fault, which runs parallel to the Karakax river, cuts and left-laterally displaces by tens to hundreds of meters most of these tributary landforms (Figs. 2 and 3). This ideal setting creates piercing points on each side of the fault that can be used to measure offsets, with assessable uncertainties thanks to the fairly linear geometry of the terrace risers.

We combined field measurements and high-resolution satellite image interpretation to map active fault strands and offset geomorphic features, particularly within the Taersa paleo-fans and inset terraces (Fig. 3). In the field, using a tape, we first measured horizontal strike-slip offsets smaller than $30 \mathrm{~m}$. We also used a Riegl VZ-1000 terrestrial LiDAR (angular resolution of $0.02^{\circ}$ for raw data) to scan the Taersa fan and fan/terrace surfaces (five bases, Fig. 3b,d). After generating the point cloud using Riegl's "RiscanPro" software, we exported the data into "Global Mapper" to build a Digital Elevation Model (DEM) with a resolution of $0.5 \mathrm{~m}$. We then extracted topographic profiles from the DEM and precisely measured cumulative horizontal and vertical fault offsets (Fig. 5). All DEM-derived measurements were compared with those directly measured in the field. Our high-resolution DEM, combined with the Ikonos satellite image of the entire Taersa site, was finally used to quantify the overall geometry of the fans and their offsets by the KXF (Figs. 5 and 6b). 
151 At a more detailed level, we used the Matlab code "3D_Fault_Offsets" of Stewart et al.

152 (2018) to measure the horizontal and vertical offsets of the youngest terrace risers (T0, T0', T0”

153 and T2) (Figs. S1-S4). That code requires tracing of the fault on the DEM and identifying

154 polygons to delineate terrace risers on both sides of the fault. Channel meandering along the

155 various risers requires reducing the width of the polygons. The DEM uncertainties were set to be

$1560.5 \mathrm{~m}$, and $2 \mathrm{~m}$ for the position of the fault whose dip was taken to be $70 \pm 10^{\circ}$ (from trenching by

157 Li et al., 2012).

158 We also show in Figure 4 the DEM $(9.78 \mathrm{~cm} /$ pix $)$ that we recently obtained across the

159 Longmu Co fault, where it offsets the highest shoreline of Sumxi-Longmu Lake (location in Fig.

160 1a). That DEM was built by merging dozens of photos taken by our Unmanned Aerial Vehicle

161 (UAV, DJI Phantom 4) using the software "Agisoft Metashape Professional”.

162 Our dating of fans and terraces at Taersa was based on the collection of a total of 35 quartz-

163 rich cobbles ( $<25 \mathrm{~cm}$ in diameter) on the surfaces, as well as of nine samples in two depth

164 profiles (down to $\sim 140 \mathrm{~cm}$ ) (Figs. 3, 8 and S5). From these samples, we obtained $35{ }^{10} \mathrm{Be}$ and six

$165{ }^{26} \mathrm{Al}$ cosmogenic model ages (Table 1). The clear desert varnish coating all the cobble surfaces

166 (Figs. 8 and S5) (Farr and Chadwick, 1996), including on the lowest, youngest terraces, strongly

167 suggests an absence of post-depositional reworking, and minimal rock weathering. The cobbles

168 were crushed and sieved, and mineral separation and quartz cleaning were performed following

169 standard procedures (e.g., Kohl and Nishiizumi, 1992). ${ }^{10} \mathrm{Be}$ and ${ }^{26} \mathrm{Al}$ model ages were calculated

170 using the Lifton et al. (2014) 'LSDn' model in CRONUS version 3 (Balco et al., 2008) and are

171 reported with $1 \sigma$ uncertainties (Table 1). The model ages from the two depth profiles were

172 calculated using the Hidy et al. (2010) software (version 1.2). 
173 We used statistical analyses based on Chauvenet's criterion (Bevington and Robinson, 2002)

174 to discard potential outliers (including samples with excessive or insufficient ${ }^{10} \mathrm{Be}$ or ${ }^{26} \mathrm{Al}$

175 concentrations) out of the age distributions. Slip rates during different time spans were then

176 derived from the ranges of fan and terrace riser offsets and abandonment ages using the method

177 of Zechar and Frankel (2009). We report the median rates (with uncertainties at the $68.27 \%$

178 confidence interval about the median) obtained using their Gaussian uncertainty model. 

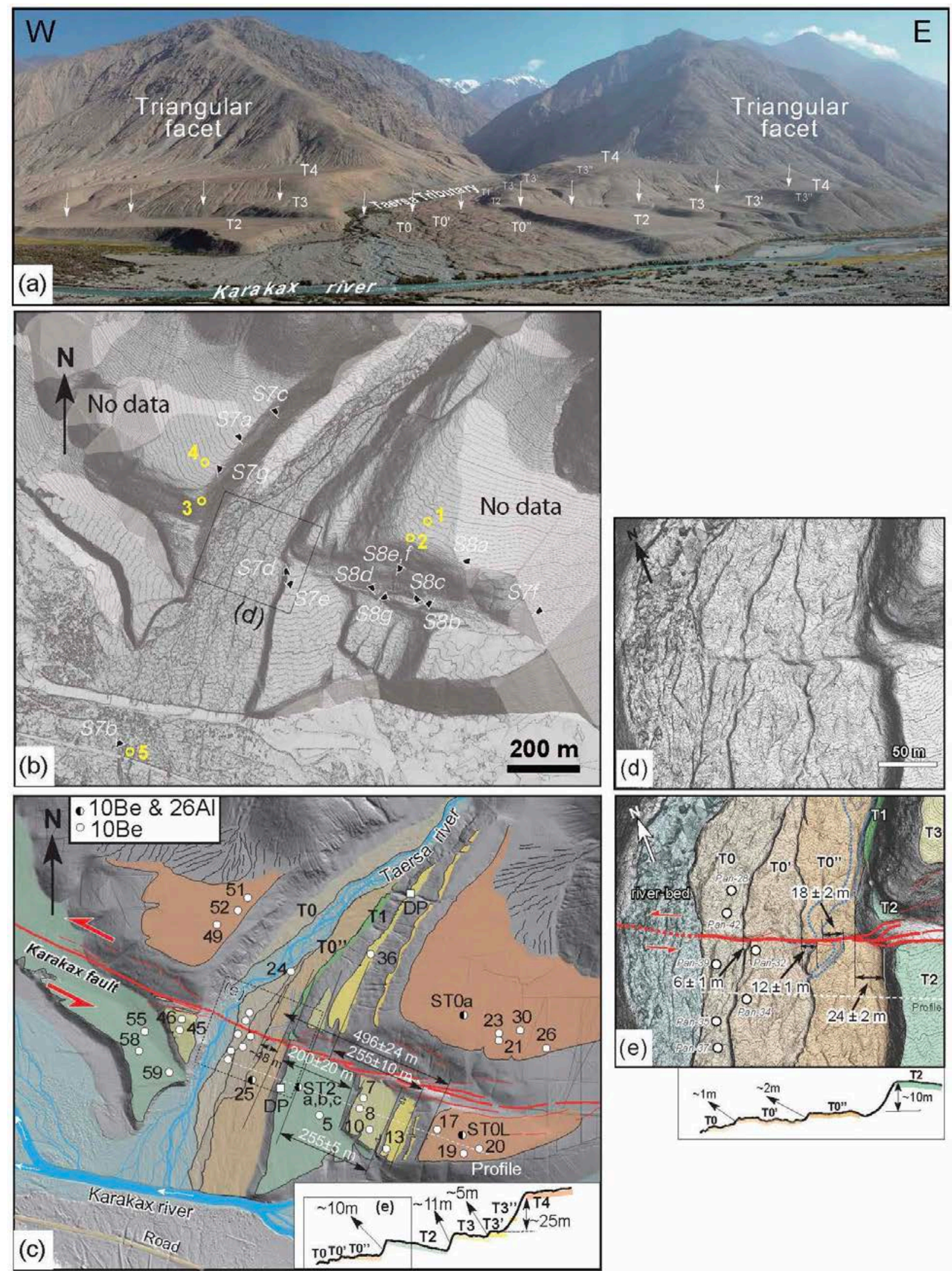
181 Figure 3. Taersa terraces site: (a) View to NE of offset Taersa terraces and triangular facets.

182 White arrows indicate main surface trace of Karakax fault. Note similar, maximum elevations of

183 highest T4 fan surfaces on either side of the Taersa tributary valley. Location of photos in

184 Figures S7 and S8 is indicated. (b and d) LiDAR DEM images (with I and $0.2 \mathrm{~m}$ contour lines,

185 respectively), with (c and e) detailed field-based mapping of TO-T4 alluvial surfaces (colored)

186 and seismic offsets, respectively. White areas in b are shielded from LiDAR surveys and five

187 yellow circles show positions of survey bases. Small white circles (with numbers) indicate

188 locations of dated cosmogenic surface samples. White squares labeled 'DP' are locations of

189 depth profiles on T3' north of the fault and T2 south of the fault. Double arrows with numbers

190 (in c) are apparent offsets of T4-T3'-T3 fan risers east of Taersa Holocene TO'/TO' fluvial

191 channel (see text for details). Bottom right insets show profiles parallel to the fault (white dashed

192 lines in $c$ and e) across alluvial surfaces, extracted from LiDAR DEM. Single arrows with

193 numbers (in e) point to single and cumulative co-seismic offsets of lowest TO to T2 terrace risers. 

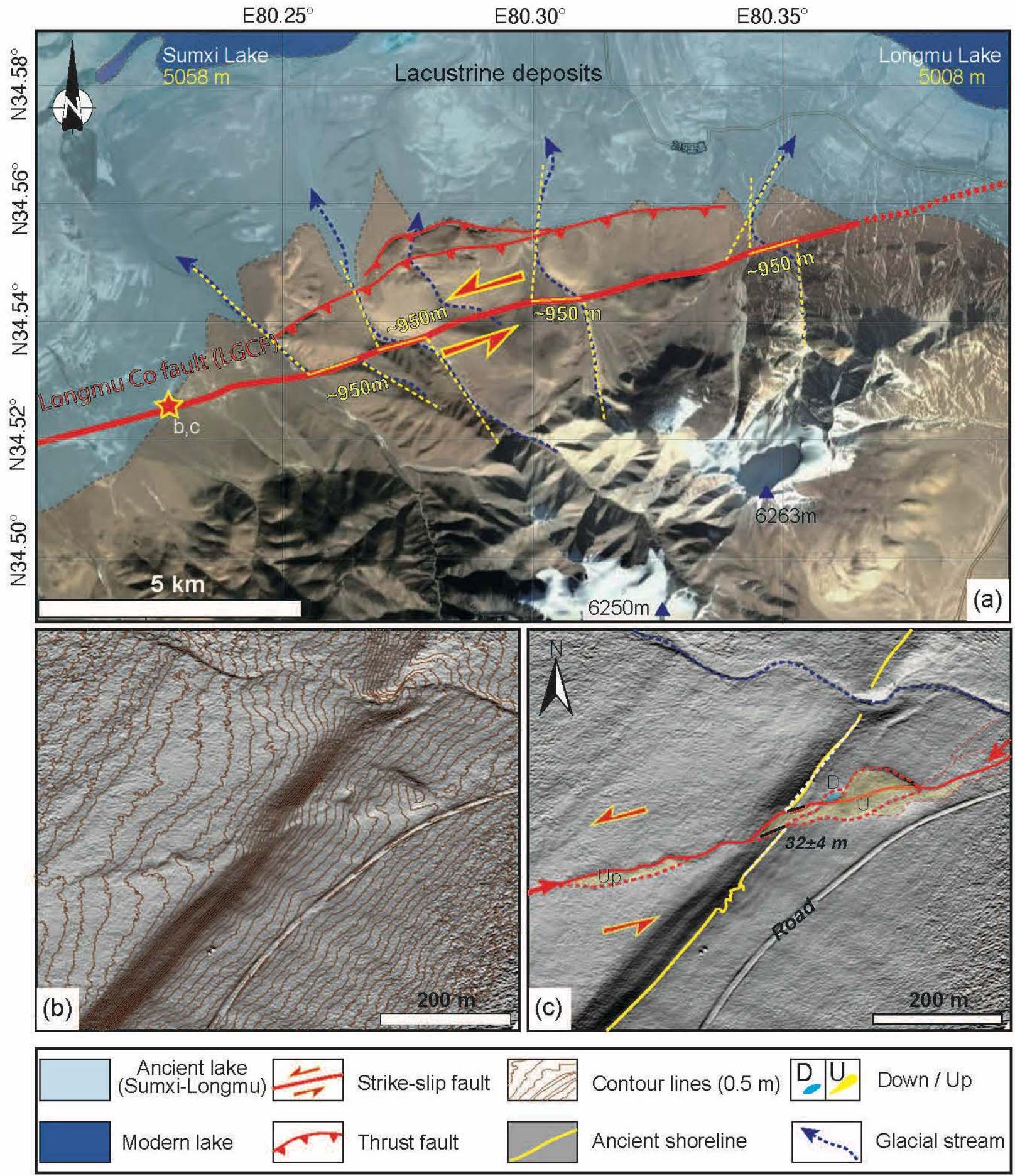

195 Figure 4. Late Quaternary offsets along Longmu Co fault south of Sumxi-Longmu Lakes: (a)

196 Active trace of left-lateral fault and associated thrusts. Post-Marine oxygen Isotope Stage MIS-6

197 glacial valley offsets $(950 \pm 50 \mathrm{~m})$ and location of offset of highest shoreline of paleo-Sumxi-

198 Longmu Lake are indicated by dashed blue lines and red star, respectively. (b) UAV-derived

199 DEM and (c) cumulative surface breaks and highest shoreline ( $6 \mathrm{ka}$ ) offset ( 32 m), with push- 
ups (Up, yellow shades) and pull-apart (Down, blue shade). Figure location is indicated in

201 Figures la and 13a. See text for details.

\section{Morphology, extent and offsets of the Taersa fans/terraces}

The Taersa site exposes four main alluvial fan and terrace surfaces (from T0, youngest, to

205 T4, oldest), with several smaller, intermediate sub-levels (nine in total, Fig. 3). The broadest

206 levels (T2, T3-T3' and T4) extend far on both sides of the Taersa tributary valley, north of the

207 Karakax river. They correspond to three main generations of large interglacial fill-fans, that

208 spread out broadly as the tributary reached into the main river valley. The curved, convex-

209 upward, shapes of most of the uplifted terraces indicate that they correspond to conical alluvial

210 fan surfaces (e.g., Meyer et al., 1996; Peltzer et al., 2020), which accounts for their slightly

211 different elevations east and west of the tributary valley (Fig. 5b). Most of the other tributary

212 streams have deposited similar imbricated alluvial fan surfaces along the Karakax valley (Li et

213 al., 2012; Peltzer et al., 2020). The lowest/youngest terraces (T0, T0', and T0"), not far from the

214 current river-bed, are covered with small boulders ( $<1 \mathrm{~m}$ in diameter, Figs. 8f,g and S5)

215 deposited along recent, well-preserved braided channels (Fig. 3d). They are separated by small

216 risers, 1-2 m-high at most (Figs. 3e and 5e). North of the fault, one additional young (low)

217 terrace (T1) has been narrowly preserved (Fig. 3c,e), which we interpret to attest to the oblique

218 component of footwall uplift north of the fault (Fig. 5a,c). Such uplift also promoted stronger

219 lateral erosion of the upstream risers, hence affected their geometries more than that of their

220 shielded counterparts south of the fault and east of the tributary (e.g., Cowgill, 2007; Gold et al., 221 2009; Mériaux et al., 2012).

222 The much smoother, higher fan surfaces T2-T4 are covered with fewer cobbles (Fig. 8b-e). 223 South of the fault, their risers are higher than those of the T0s-T1 flight, from 5 to $25 \mathrm{~m}$, up to a 
224 maximum of $56 \mathrm{~m}$ above the present-day river-bed (Figs. 3c,e, insets and 5). North of the fault, 225 that maximum height reaches $\sim 70 \mathrm{~m}$ (Fig. 5b). This shows that here, the Karakax main sinistral 226 strand has a significant normal slip component, which we interpret to reflect extension along the 227 northern edge of a pull-apart sag beneath the swampy meanders of the Karakax river east and 228 west of Taersa (Fig. 2). Note that this pull-apart also corresponds to a southwestwards step where 229 the main fault trace crosses the Karakax river from north to south. The pull-apart-related, 230 extensional component has been long-lived since the cumulative vertical throw of fan surfaces 231 T2 to T4 across the fault increases from 2 to $28 \mathrm{~m}$ (Fig. 5c). Also, the presence of triangular 232 facets on both the north and south sides of the Karakax valley along mainly that stretch of the 233 KXF supports long-term extension across that pull-apart sag (Figs. 2, S7f and S8f).

234 On the eastern side of the Taersa tributary floodplain, the $\mathrm{T} 0^{\prime} / \mathrm{T} 0$ and $\mathrm{T} 0$ "'/T0' risers, one 235 large fluvial paleo-channel within T0", and the T2/T0" riser (recall that T1 is not present south of 236 the fault) are left-laterally offset by $6 \pm 1,12 \pm 1,18 \pm 2$, and $24 \pm 2 \mathrm{~m}$, respectively (Fig. 3e), as 237 measured in the field with a tape (Li et al., 2012). Note that the offsets of the channel axes and of 238 the tops and bases of their bounding risers are indistinguishable and that, because of exceptional 239 preservation due to the arid climate, the error bars on their offsets are generally on order of $10 \%$.

240 Using Stewart et al. (2018)'s “3D_Fault_Offsets” code, the corresponding, best-fitting horizontal 241 offsets are $5.9 \pm 0.5 \mathrm{~m}$ for T0/T0' (Fig. S1), $12.8 \pm 2.5 \mathrm{~m}$ for the T0’/T0” riser (Fig. S2), $17.8 \pm 1.5$

$242 \mathrm{~m}$ for the gully on T0" (Fig. S3), and $22.9 \pm 1.5 \mathrm{~m}$ for the T0"/T2 riser (Figs. S4, S6 and S7e)

243 while vertical offsets are negligible $(<1 \mathrm{~m})$. The automatic restorations thus yield offsets that are 244 consistent (at the $99 \%$ level) with our previous field and LiDAR survey measurements. The 245 largest ( 23-24 m) offset is also found across several other Holocene fans and fan risers along 246 the Karakax valley (Fig. $1 \mathrm{~b}$ and Li et al., 2012). 
The current left-lateral offsets of the higher/older T3/T2, T3'/T3 and T4/T3' riser bases and tops are $200 \pm 20,255 \pm 5$, and $255 \pm 10 \mathrm{~m}$ (Figs. $3 \mathrm{c}$ and S6) and 196 $\pm 10,255 \pm 10$ and $214 \pm 10 \mathrm{~m}$

249 (Fig. 5a), respectively. That the offset of the T4/T3' riser top ( $214 \mathrm{~m})$ is significantly smaller 250 than that of the T3'/T3 riser $(\sim 255 \mathrm{~m})$, which stands as much as $38 \mathrm{~m}$ down below T4 north of 251 the fault (Fig. 5b), and therefore must be much younger, poses problem. This implies that, here, 252 riser tops cannot simply be used to reliably measure cumulative offsets. One way to account for 253 that puzzling observation is that greater incision associated with the vertical uplift north of the 254 fault affected the now preserved apparent horizontal offsets. In addition, the presence of yet 255 another, intermediate, barely preserved terrace ledge (T3'') between T4 and T3' (Figs. 3c, 5-8)

256 implies that the total incision between the T4 and T3' levels was long-lived, and entailed several 257 distinct episodes. Such long-lasting incision events likely broadened the valley width north of the 258 fault at the T4 level by more than 2 x $70 \mathrm{~m}$ (possibly as much as $258 \mathrm{~m}$ on the east side, Fig. 6a).

259 North of the fault, this laterally eroded the currently narrow, remnant, footwall terrace ledges (T2, 260 T3, T3' and T3''), and particularly the highest uplifted T4 fan riser. On the west side of the 261 Taersa tributary, the more steeply incised valley edge $\left(\sim 30^{\circ}\right.$ east dip on average compared to $\sim 18^{\circ}$ 262 west dip on average on the east side, Fig. 6a), likely accounts for the complete demise of all 263 surfaces younger than T4, compared to the preservation of the east side ledges.

264 At a more detailed level, Figure $6 \mathrm{~b}$ shows that the average slopes of the risers on the east 265 side of the Taersa tributary decrease stepwise upwards from $\sim 25^{\circ}$ to $\sim 18^{\circ}$, as their overall 266 convexity increases with height, hence age, above river. This is consistent with the much greater 267 degradation of the riser slopes north than south of the fault, which is clear on both the Ikonos 268 imagery (Fig. 6c,d) and in the field (Fig. 8a). The composite T4/T3''/T3' riser, in particular, has 269 been much more strongly incised by deeper and more numerous gullies perpendicular to the 
270 Taersa tributary north than south of the fault (Figs. 6c,d and S7a). That the gullies south of the

271 fault are narrower and shallower than those to the north is supported by the multiple yak/sheep

272 paths that cross them, while none are observed to the north (Fig. 6c,d). Note that similar,

273 asymmetric, fan/terrace aggradation and degradation processes have been described elsewhere

274 along the eastern Altyn Tagh fault (e.g., Pingding Shan, Mériaux et al., 2012). Clearly, the strong

275 erosional degradation of the highest, T4/T3' riser east of the Taersa tributary, and its correlative

276 eastward retreat, make it challenging to use its present geometry to constrain a total cumulative

277 offset in a traditional way.

278 In order to do so, one must factor in that the top offset must have been greater than apparent

279 today (214 m, Fig. 5a). Before tectonic uplift and correlative river incision and valley widening

280 north of the fault (Fig. 6a), the initial, upstream position of the top of the western riser of T4 east

281 of the tributary (and to a lesser degree, possibly also of those of T3, T3' and T3'") must have

282 been closer to the eastern edge of the Taersa tributary floodplain. A plausible position for the

283 original western edge of $\mathrm{T} 4$ east of the tributary might have been between the present $\mathrm{T} 0$ "'/T0'

284 and T1/T0" risers, which mark the current minimum and maximum limits of that floodplain, $\sim 48$

$285 \mathrm{~m}$ apart (Fig. 3c). This would also be in keeping with the fact that the upstream Taersa tributary

286 valley is deeply anchored, hence captive, within basement rocks that crop out on either side of

287 the tributary valley almost all the way down to the KXF (Figs. 3a and S7). Consequently, the 214

$288 \mathrm{~m}$ apparent riser top offset of T4 might be increased to an average of $496 \pm 24 \mathrm{~m}$ (Figs. 3c and 7).

289 The two highest risers north and south of the fault are T4/T3' and T3/T2. The T3'/T3 riser,

290 which is only $\sim 3$ to $5 \mathrm{~m}$-high, compared to $\sim 25 \mathrm{~m}$ for T4/T3' and $\sim 12 \mathrm{~m}$ for T3/T2 (Fig. $5 \mathrm{~b}$ ),

291 appears to be an intermediate feature, likely linked with a minor aggradation/incision change

292 between the main climatic episodes that have shaped the Taersa tributary valley and alluvial fan 
293 deposition. In addition, south of the fault trace, the T3'/T3 riser may have been degraded by the

294 passage and recent incision of the large, mountain-sourced gullies that cross obliquely westwards

295 most of the fan surfaces all the way to the Karakax river (Figs. S8 and S9). The fact that the

$296 \mathrm{~T} 3^{\prime} / \mathrm{T} 3$ riser offset (indistinguishable top and base, $255 \pm 10 \mathrm{~m}$ ) is the same as that of the base of

297 the T4/T3' riser, while their ages ought to be different, also poses problem. However, bearing in

298 mind that T4/T3' and T3/T2 reflect the two major fan depositional events, coeval with the

299 strongest glacial-interglacial transitions, the T3'/T3 offset value should nevertheless be taken

300 into account.

301 The largest possible offset of the T4/T3' riser top (496 $\pm 24 \mathrm{~m})$ is comparable to that of the

302 southeasternmost T4 fan outer limit along the Karakax river ( $\sim 500 \pm 50 \mathrm{~m}$, Fig. $7 \mathrm{a}, \mathrm{b})$. That latter

303 offset, as reconstructed in Figure 7a, also realigns the T4/T3' riser top south of the fault with the

304 current eastern limit of the Taersa floodplain north of the fault (equivalent to the T0"/T0' riser),

305 which independently validates the inference made regarding the initial position of that riser. As

306 shown in Figure 7c,d, it is also possible to use 10 m-resolution, Tandem-X DEM data to assess in

307 section the reconstruction of the initial T4 fan geometry. The best reconstructed fan shape

308 corresponds to horizontal and vertical back-slip displacements of $\sim 500 \pm 50 \mathrm{~m}$ and $\sim 40 \pm 10 \mathrm{~m}$,

309 respectively. Such a $\sim 500 \pm 50 \mathrm{~m}$ horizontal back-slip is the largest to still preserve a $\sim 130 \mathrm{~m}$ -

310 wide passage for the Taersa tributary channel, broad-enough for it to flow between the T4W

311 upstream and T4E downstream risers at the time $(206 \pm 25 \mathrm{ka})$. This corroborates the inference

312 that, on both its west- and southeast-facing limits, the original geometry of the T4 fan since

313 abandonment has accrued approximately $500 \mathrm{~m}$ of sinistral offset along the KXF. 
314 Lastly, it should be noted that the offset of the T3'/T3 riser at Taersa ( 255 $\pm 10 \mathrm{~m})$ is

315 commensurate with that of the corresponding Eemian T4 fan reconstruction ( $300 \pm 20 \mathrm{~m})$ at Site 4

316 in Peltzer et al. (2020) located $18 \mathrm{~km}$ to the east (Fig. 1b). 


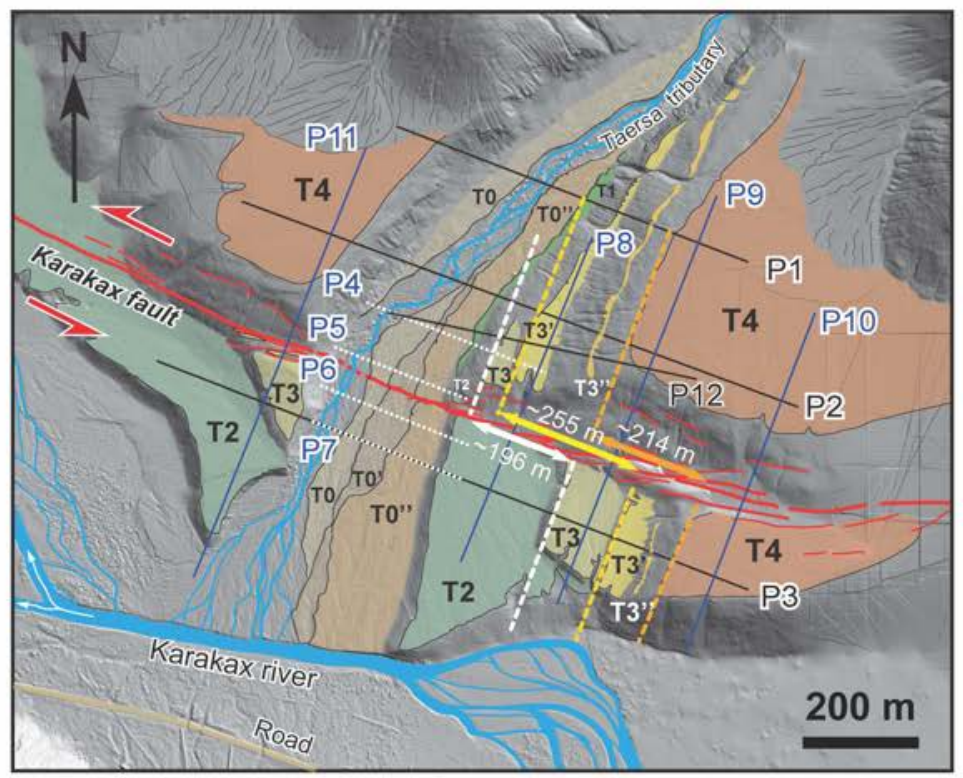

(a)
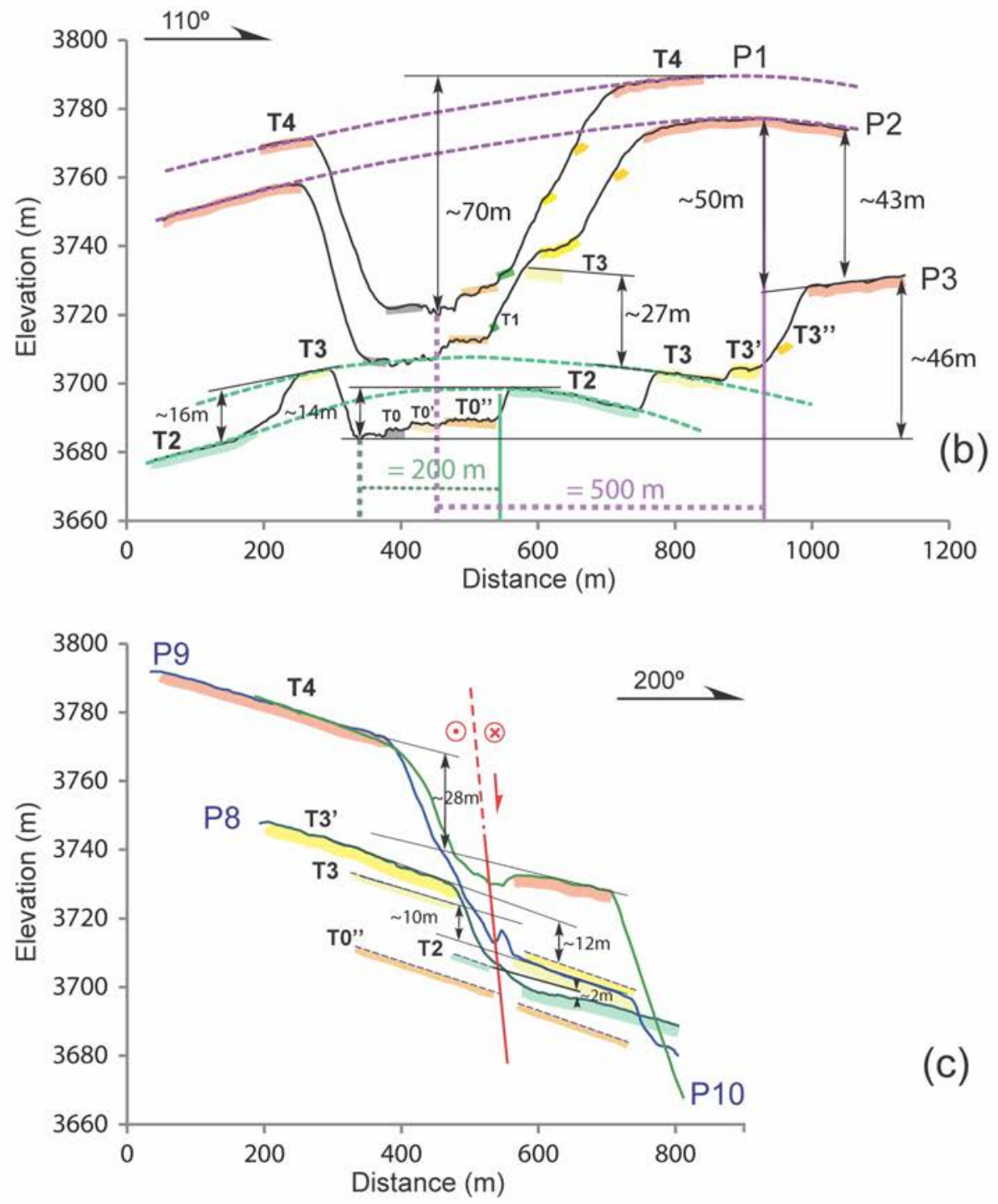

(c) 

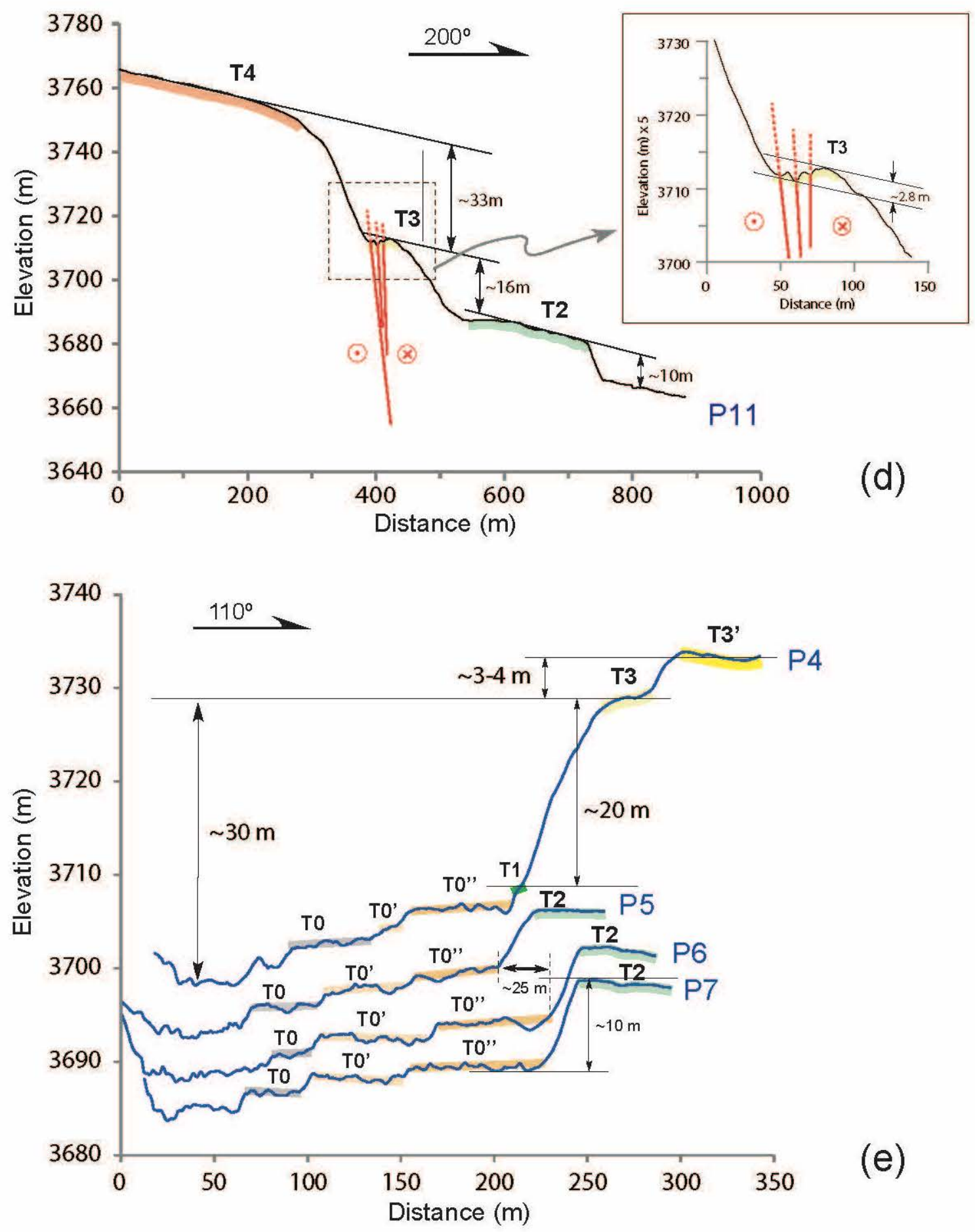

320 Figure 5. (a) Annotated LiDAR DEM of Taersa fan and terrace surfaces with location of

321 LiDAR-survey topographic profiles parallel (b and e) and perpendicular (c and d) to the

322 Karakax fault (vertical exaggeration x5). Note convex-upwards shape of profiles parallel to fault

323 (purple and green dashed lines), demonstrating fluvial fan origin of surfaces. Numbers indicate 
324 relative heights and distances between fan top (apex) and river bed (200 and $500 \mathrm{~m})$, up- and

325 downstream from the fault, respectively. Maximum cumulative co-seismic offset on TO" $(25 \mathrm{~m})$

326 is also indicated in (e). Note the uplifted, remnant shutter ridges (likely derived from the

327 displacement of T4) in C (P9) and d (P11). Profile P12 is shown in Figure 6b.

328 

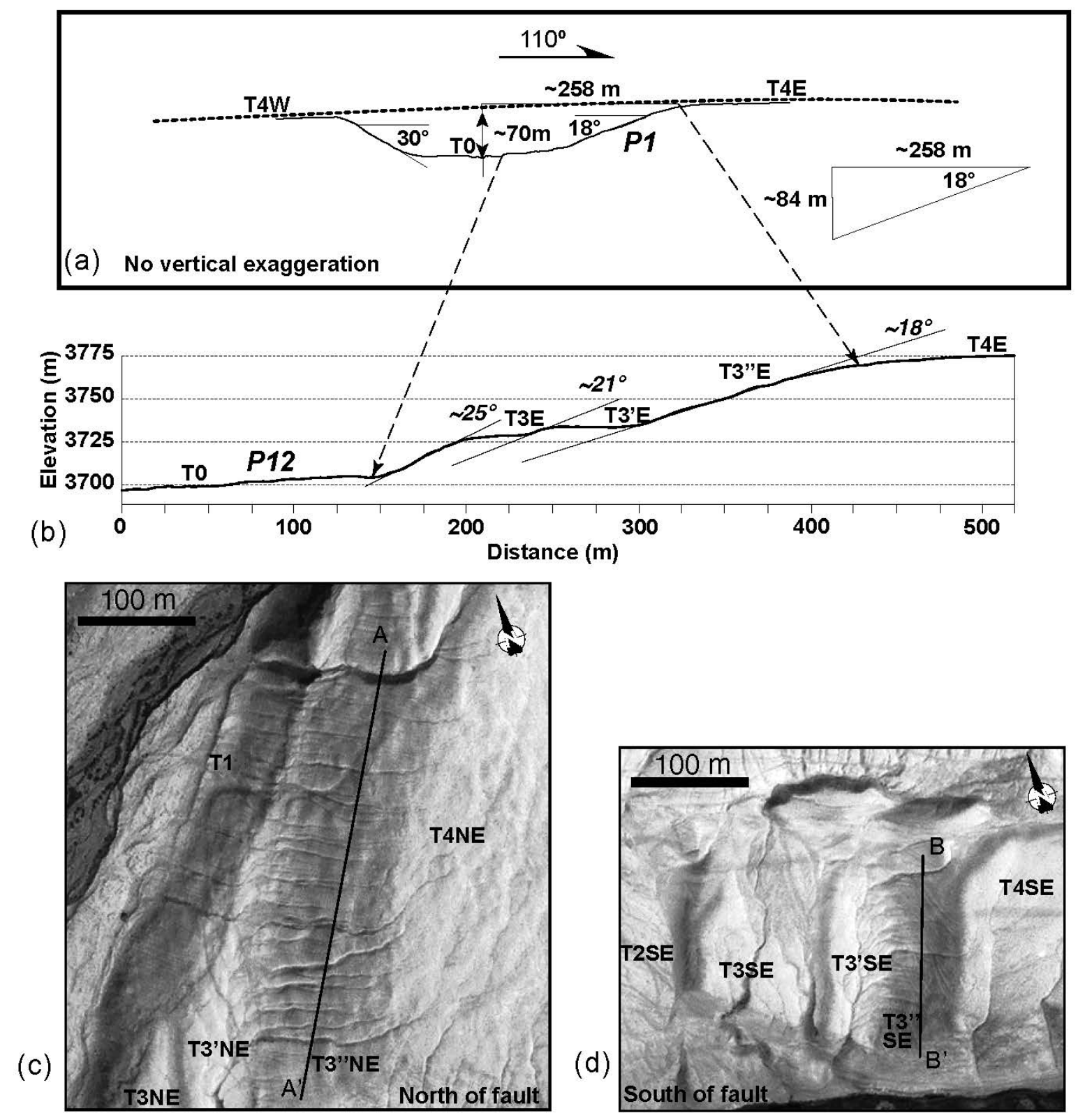

(d)
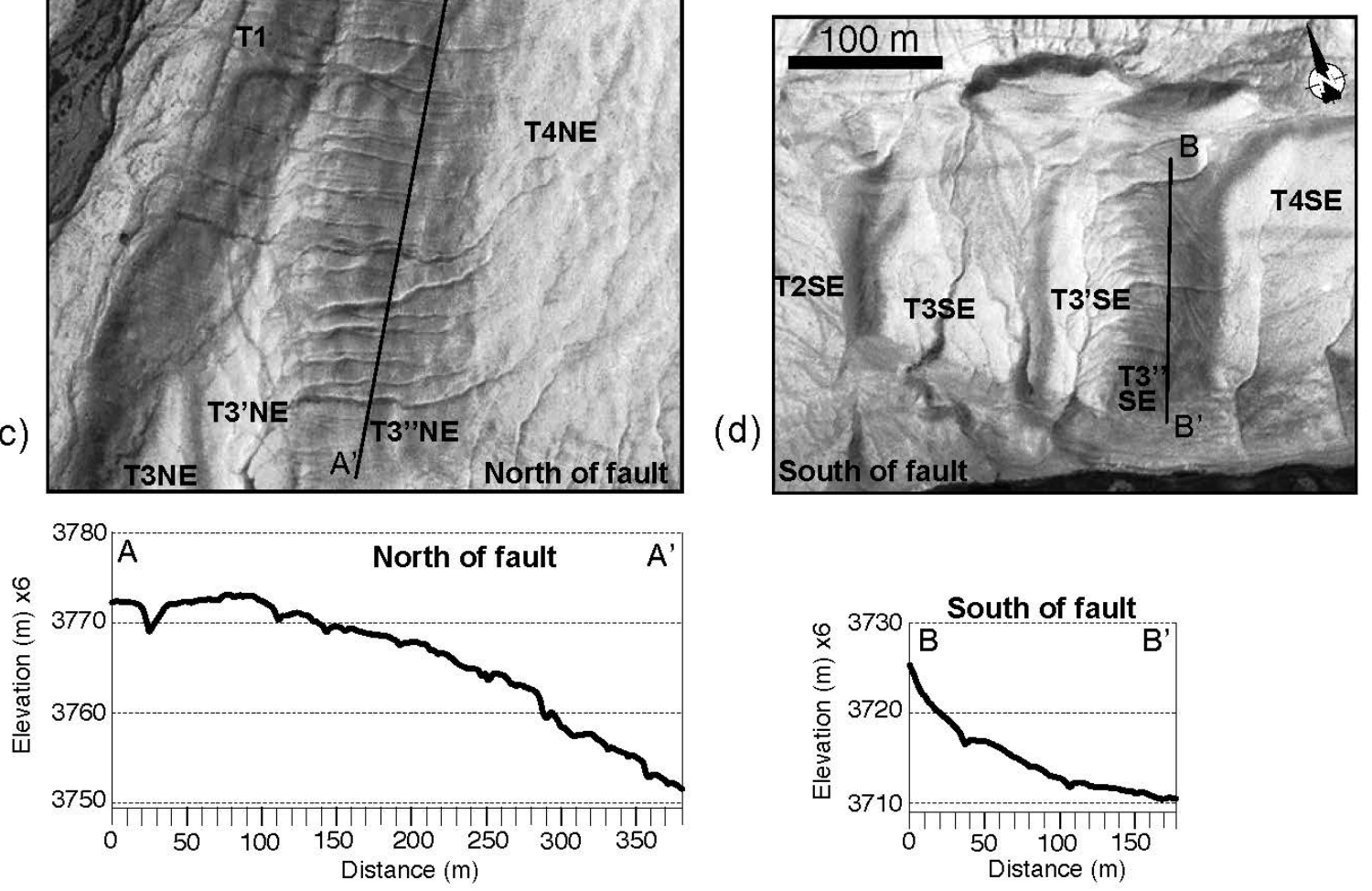

330 Figure 6. Morphology of the Taersa risers: (a) Profile P1 (see location in Fig. 5a) showing

331 comparable elevations of T4E and T4W north of fault with incision depth of Taersa tributary, 
332 and average upstream valley slopes. (b) Higher resolution profile (P12 in Fig. 5a) showing step333 wise steepening $\left(18\right.$ to $\left.25^{\circ}\right)$ of average riser slopes (T4/T3', T3'/T3, T3/T1) as a function of

334 younger age. (c and d) Close-up of Ikonos image (see location in Fig. 7a) showing varying

335 degrees of rill incision on west-facing risers north and south of fault, respectively. 

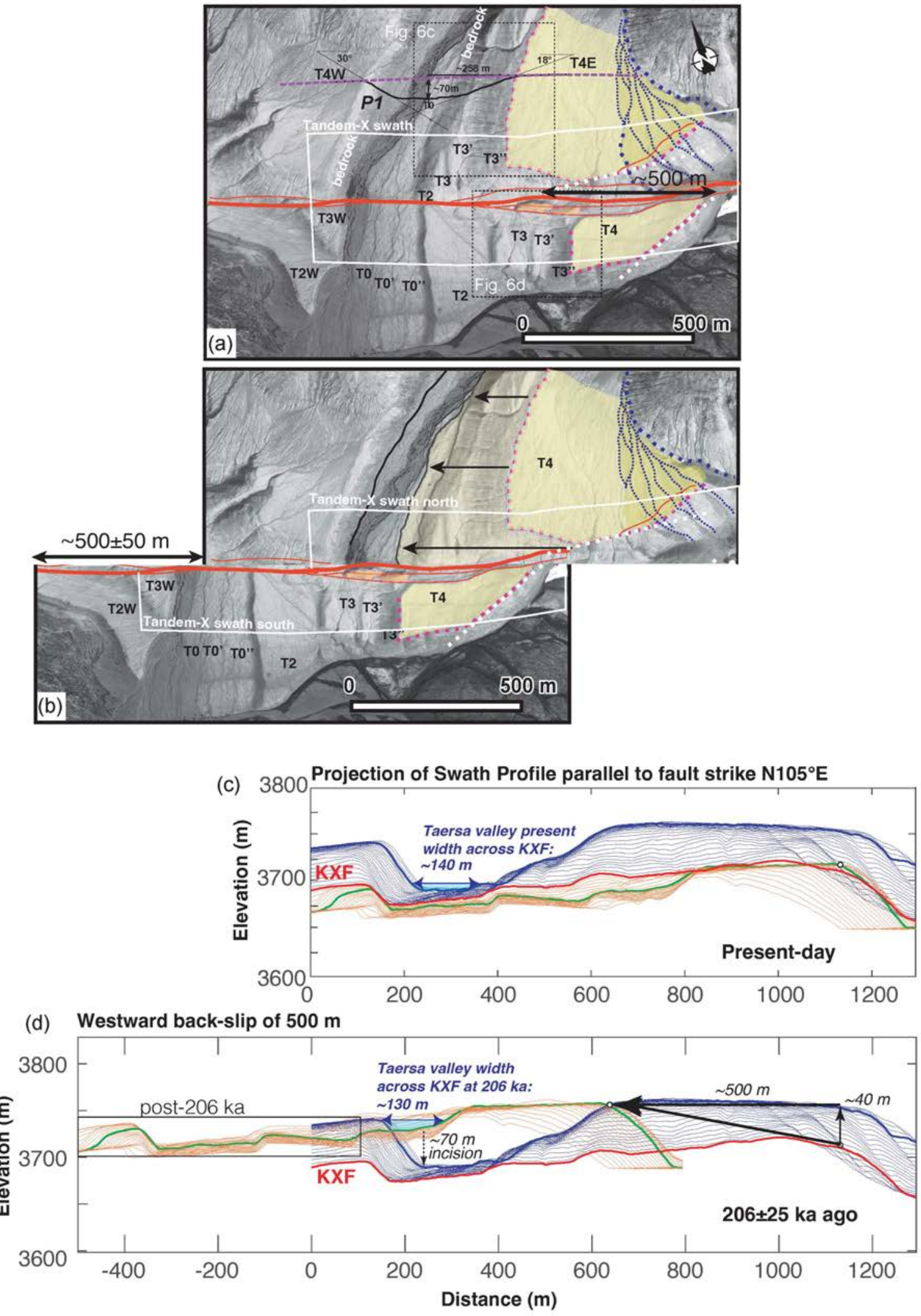
338 Figure 7. Reconstruction of the complete sinistral offset of oldest T4 fan surface taking into 339 account normal component of uplift along left-lateral Karakax fault at Taersa site: (a) Ikonos

340 image-based interpretation of T4 fan surface (pale yellow) including younger drainages to the 341 east (on darker yellow fan). Position of profile in Figure 6a is indicated across upstream Taersa 342 valley. East-west elongated, orange hills along main KXF trace (red) are shutter ridges likely 343 derived from T4 (see also profiles in Fig. 5c,d). (b) Reconstruction of complete shape of T4 fan

344 before uplift of T4north and incision of Taersa tributary north of fault, consistent with a $345 \sim 500 \pm 50 \mathrm{~m}$ total offset of both western and southeastern edges of fan. See text for details. (c) 346 Projection, along KXF at Taersa, of 400 m-wide topographic profiles swath (20 south of fault, 347 red; 20 north of fault, blue) from Tandem-X DEM (vertical exaggeration $x 2$ ). Red line is KXF 348 fault trace. Thick dark blue line is present envelope of highest surface (T4) across Taersa valley 349 (light blue shade) north of fault. Thick green line is present envelope of highest surfaces (T4-T3'350 T3) across Taersa valley south of fault. (d) Reconstruction of $\sim 500 \mathrm{~m}$ westward back-slip (as in b) 351 of red profiles south of fault (vertical exaggeration x2). Note preservation of $\sim 130 \mathrm{~m}$-wide valley 352 width across fault at $\sim 206 \mathrm{ka}$, similar to present valley width $(\sim 140 \mathrm{~m})$. Black vectors to the right 353 indicate vertical and left-lateral offsets across KXF since $206 \mathrm{ka}$. 

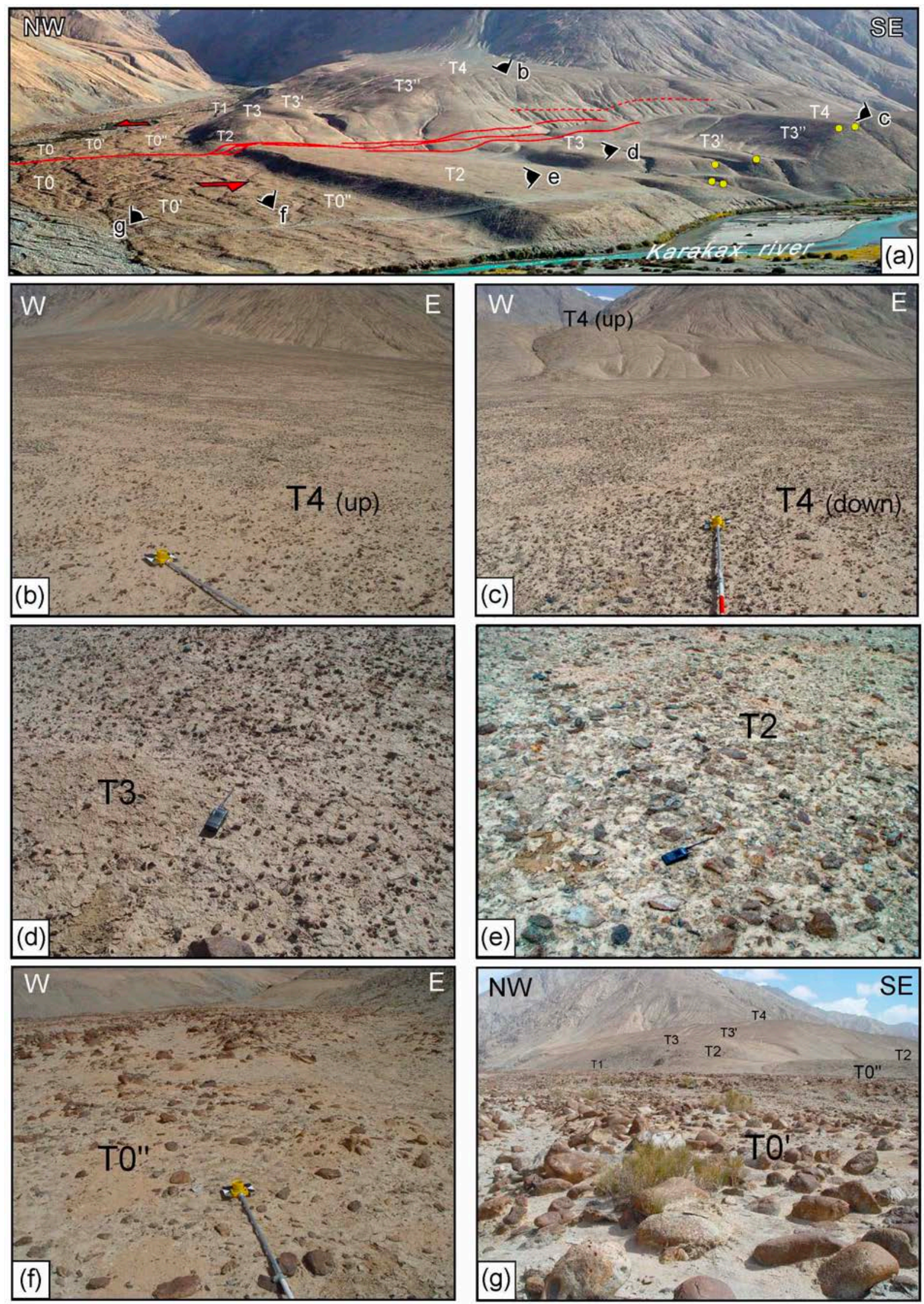
Figure 8. Field photographs of Taersa fan and terrace surfaces (a) showing distinct cobble sizes and surface roughness as a function of abandonment age north (b) and south (c-g) of the fault. The younger the surface the larger and coarser the samples, as expected. Yellow circles indicate locations of Optically Stimulated Luminescence (OSL) samples from Gong et al. (2017). See text for discussion.

\section{$4{ }^{10} \mathrm{Be},{ }^{26} \mathrm{Al}$ cosmogenic surface and depth profile dating of the alluvial surfaces}

The ages of the 35 samples dated on the alluvial surfaces along either sides of the fault and Taersa tributary valley (Fig. 3c) are shown in Table 1 and plotted in Figure 9.

The youngest ${ }^{26} \mathrm{Al}$ age on $\mathrm{T} 4$ may be statistically rejected as a clear outlier, using Chauvenet criterion, while the 13 remaining ages $\left(12{ }^{10} \mathrm{Be}\right.$ and one ${ }^{26} \mathrm{Al}$ on both $\mathrm{T} 4 \mathrm{E}$ and $\left.\mathrm{T} 4 \mathrm{~W}\right)$ range between 162 and $245 \mathrm{ka}$, with an average of $206 \pm 25 \mathrm{ka}(1 \sigma)$. This confirms that the highest T4 surfaces belong to the same large fan on both sides of the Taersa tributary. Note that the T4 alluvial surface dated at Taersa (the oldest age is $245 \pm 16 \mathrm{ka}$ ) is amongst the oldest ever dated in and along the margins of Tibet (e.g., Hetzel et al., 2002; Blisniuk and Sharp, 2003; Tao et al., 2020). This attests that regional erosion of the surface tops is minimal, as previously suggested in other areas of NE Tibet (e.g., Hetzel et al., 2002).

The two sample ages on T3' (191 and $215 \mathrm{ka}$ ) yield an average age of $203 \pm 18 \mathrm{ka}$, comparable to that of T4. The narrow widths of T3', at the base of the high T4/T3' risers that bound the west sloping surfaces of T4 (Fig. 3c), suggest that both samples might have foundered from T4, likely due to co-seismic shaking. High-resolution satellite images and broad-scale field photograph (Fig. 8a) confirm that much of the T4/T3' riser slope is covered with large boulders that have toppled down during rockfalls. This likely accounts for their apparently similar ages, despite the large elevation difference ( $\sim 43-50 \mathrm{~m}$ north, and $\sim 25 \mathrm{~m}$ south of the fault, Fig. $5 \mathrm{~b}$ ). 
380 The age distribution on T3 is completely different east and west of the Taersa tributary (Fig. 9).

381 To the east, the concordant average ages of the three samples is $185 \pm 2 \mathrm{ka}$, a value roughly

382 consistent with the average ages on T3' and T4. We thus infer that they were similarly

383 transported out of T4, likely along the large south-flowing gullies that drain it (Figs. S8 and S9).

384 To the west, by contrast, the two samples collected on the surface of the small remnant of T3, 385 which is separated from T4 by a $\sim 2-3$ m-deep sag along the fault (Figs. 3 and 5 d), have much

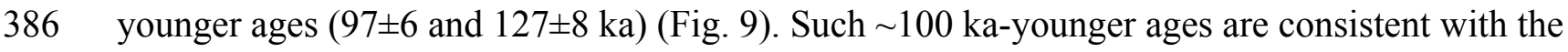
387 elevation differences between T4 and T3 ( $\sim 33 \mathrm{~m}$, Fig. 5d), or T3 and T0 ( $26 \mathrm{~m}$, Fig. $5 \mathrm{~d})$ on the 388 Taersa tributary west bank. These ages are also similar to those found by Peltzer et al. (2020) on 389 their highest surfaces (T4) $\sim 30 \mathrm{~m}$ above the local tributary at their Site 4. Hence, although we 390 have only two in situ ages for now, we infer that the average age (112 $\pm 21 \mathrm{ka})$ of our two samples 391 on T3W represents the actual age of the Taersa T3-T3' surfaces. At a more detailed level, one 392 might further hypothesize that the small, 3-5 m-high riser between T3 and T3' east of the 393 Taersa tributary corresponds to that observed by Peltzer et al. (2020)'s between their T3 and T4 394 surfaces at their Site 4. In that case, the T3 and T3' fan surfaces at Taersa would be even closer

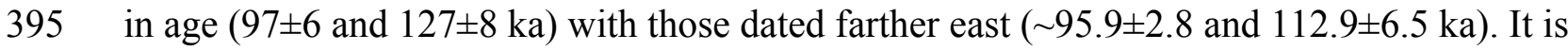
396 clear, however, that additional sampling would be needed to confirm that inference.

397 At the level of T3' north of the KXF, one depth profile was retrieved from a refreshed riser 398 in a deep incision that reaches the top of T4 (Figs. 3c and S7). Four individual cobbles collected 399 between 55 and $120 \mathrm{~cm}$-depths yield consistent ${ }^{10} \mathrm{Be}$ and ${ }^{26} \mathrm{Al}$ model ages of $\sim 260$ and $~ 256 \mathrm{ka}$ 400 (Fig. 10). Such ages, however, are $\sim 50$ ka older than the average age ( $\sim 206 \mathrm{ka})$ of the T4 surface 401 above, which is stratigraphically puzzling. They might be interpreted to date reworked colluvium 
402 derived from the erosion of surfaces higher than T4, upstream along the Taersa tributary. In any

403 case, these old 'inherited' ages must predate the abandonment of either T3' or T4.

404 On T2, which is well-preserved only south of the fault, ten surface sample ages (seven ${ }^{10} \mathrm{Be}$ 405 and three $\left.{ }^{26} \mathrm{Al}\right)$ fall between 11 and $30 \mathrm{ka}$, with an average age of $19 \pm 7 \mathrm{ka}$. Three ages $(\sim 28 \pm 2 \mathrm{ka}$ 406 on average), are significantly older, by $\sim 10 \mathrm{ka}$, than the majority of the seven others (average of $40716 \pm 3 \mathrm{ka}$ ). One depth profile in the refreshed eastern T2/T0" riser (Fig. S5) yields model ${ }^{10} \mathrm{Be}$ and $408{ }^{26} \mathrm{Al}$ surface ages between 11 and $20 \mathrm{ka}$ (average of $15.5 \pm 4.5 \mathrm{ka}$ ), after rejection of two clear 409 outliers (Fig. 10). Such concordant ages confirm that T2, which fans out of the Taersa gorge into 410 the Karakax valley, is best interpreted as a fan-shaped fill terrace, resulting from post-glacial 411 melting.

412 The morphologies of the lowest terraces (T0-T0'-T0"), that stand $10 \mathrm{~m}$ below T2 but only 413 1-2 $\mathrm{m}$ above each other and the present-day river bed, are similar, with remarkably well414 preserved braided channels (Figs. 3d,e, 5e and S7b). They must therefore be significantly 415 younger than T2 ( 16 ka). The unique sample on T0", with ages of $32 \mathrm{ka}\left({ }^{10} \mathrm{Be}\right)$ and $29 \mathrm{ka}\left({ }^{26} \mathrm{Al}\right)$ 416 (average of $31 \pm 2 \mathrm{ka}$ ) must thus be an outlier derived from erosion of T2. Likewise, the two ${ }^{10} \mathrm{Be}$ 417 samples on T0' (16 and 24 ka with an average of $20 \pm 6 \mathrm{ka}$ ) must also be outliers derived from T2. 418 Finally, the six samples on T0 include two $\sim 20 \mathrm{ka}$ and four $10 \pm 2 \mathrm{ka}$ ages, consistent with 419 inheritance of the two older cobbles, while the youngest majority reflects T0's actual Holocene 420 age. 


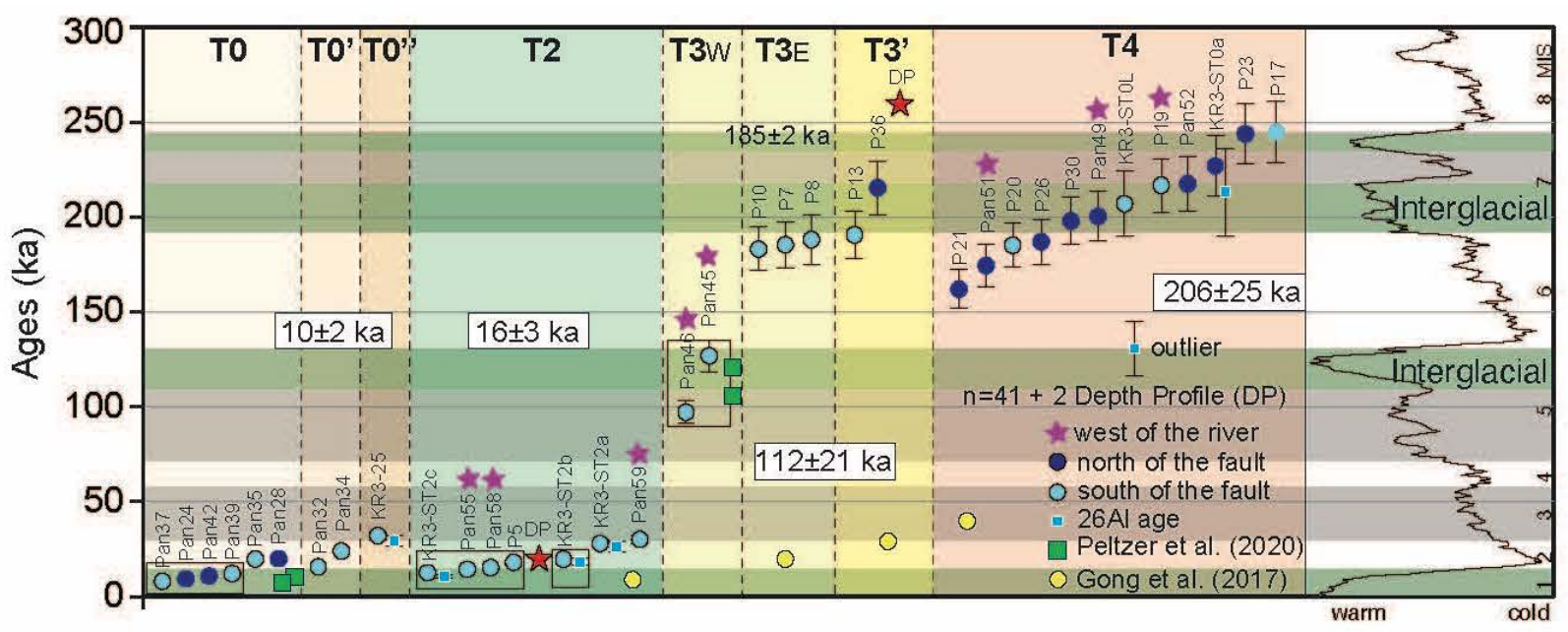

422 Figure 9. Ages at the Taersa site. ${ }^{10}$ Be and ${ }^{26}$ Al surface-exposure cosmogenic ages (numbered 423 as in Fig. 3c,e and Table 1) using the Lifton et al. (2014) 'LSDn' model in CRONUS version 3,

424 with $1 \sigma$ uncertainties. Ages in white boxes are average of all individual ages for T4, and average 425 of ages in thin black boxes for T3W, T2 and T0. Green squares refer to ages from Site $4 \mathrm{in}$

426 Peltzer et al. (2020) (location in Fig. 1b). Yellow circles are OSL ages from Gong et al. (2017).

427 Right panel shows global climatic proxy curve of Lisiecki and Raymo (2005), with grey-shaded 428 sectors indicating Marine oxygen Isotope Stages (MIS) 1 to 8. Green bands are interglacial 429 periods, during which glaciers melt coeval with deposition of large alluvial fans and terraces.

430 See text for details.

432 Table 1: Analytical results of ${ }^{10} \mathrm{Be}$ and ${ }^{26} \mathrm{Al}$ geochronology and surface-exposure model ages at 433 Taersa site along Karakax fault.

\begin{tabular}{|c|c|c|c|c|c|c|c|c|c|c|c|c|c|c|c|c|}
\hline $\begin{array}{c}\text { Surfac } \\
\mathrm{e}\end{array}$ & $\begin{array}{l}\text { Sample } \\
\text { name }\end{array}$ & $\begin{array}{l}\text { Lat } \\
\text { (N) }\end{array}$ & $\begin{array}{l}\text { Long } \\
\text { (E) }\end{array}$ & $\begin{array}{l}\text { Elev } \\
(\mathrm{m})\end{array}$ & $\begin{array}{l}\text { Dept } \\
\text { h } \\
\text { (cm) }\end{array}$ & $\begin{array}{l}\text { Quartz } \\
\text { (g) }\end{array}$ & $\begin{array}{l}\text { Be } \\
\text { carrier } \\
(\mathrm{mg})\end{array}$ & $\begin{array}{l}\text { Al } \\
\text { carrier } \\
(\mathrm{mg})\end{array}$ & $\begin{array}{l}\begin{array}{l}10 \\
{ }^{9} \mathrm{Be} /\end{array} \\
\left(10^{-}\right. \\
\left.{ }^{15}\right)\end{array}$ & $\begin{array}{c}{ }^{26} \mathrm{Al}^{27} \\
\mathrm{Al} \\
\left(10^{-15}\right)\end{array}$ & $\begin{array}{c}{ }^{10} \mathrm{Be} \\
\left(10^{6} \text { atom } / \mathrm{g}\right)\end{array}$ & $\begin{array}{l}{ }^{26} \mathrm{Al} \\
\left(10^{6}\right. \\
\text { atom/ } \\
\mathrm{g})\end{array}$ & (+ ext. uncert.) & $\begin{array}{l}\text { (int. } \\
\text { Uncert } \\
. \text {.) }\end{array}$ & $\begin{array}{c}\text { LSDn } \\
\text { (+ ext. uncert.) }\end{array}$ & $\begin{array}{l}\text { (int. } \\
\text { Uncert } \\
. \text { ) }\end{array}$ \\
\hline \multirow[t]{4}{*}{ TOSE } & $\begin{array}{l}\text { KXW- } \\
\text { Pan 39* }\end{array}$ & 36.33562 & 78.08641 & 3711 & 0 & 20.4503 & 0.3464 & I & $\begin{array}{c}450 \pm \\
8\end{array}$ & I & $0.509 \pm 0.009$ & I & $12155 \pm 945$ & 237 & $12155 \pm 758$ & 237 \\
\hline & $\begin{array}{l}\text { KXW- } \\
\text { Pan } 35^{*}\end{array}$ & 36.3352 & 78.0863 & 3707 & 0 & 20.050 & 0.3461 & / & $\begin{array}{c}783 \pm \\
10\end{array}$ & I & $0.903 \pm 0.012$ & / & $20261 \pm 1555$ & 279 & $19751 \pm 1204$ & 272 \\
\hline & $\begin{array}{l}\text { KXW- } \\
\text { Pan } 37^{*}\end{array}$ & 36.33505 & 78.0863 & 3706 & 0 & 20.112 & 0.3465 & 1 & $\begin{array}{c}276 \pm \\
7\end{array}$ & I & $0.318 \pm 0.008$ & I & $7908 \pm 628$ & 201 & $8059 \pm 519$ & 205 \\
\hline & $\begin{array}{c}\text { KXW- } \\
\text { Pan } \\
24^{* *}\end{array}$ & 36.33717 & 78.08839 & 3729 & 0 & 26.138 & 0.3799 & 1 & $\begin{array}{c}379 \pm \\
12\end{array}$ & I & $0.368 \pm 0.012$ & I & $9138 \pm 750$ & 299 & $9366 \pm 633$ & 307 \\
\hline \multirow{2}{*}{ TONE } & $\begin{array}{c}\text { KXW- } \\
\text { Pan } \\
28^{* *}\end{array}$ & 36.33619 & 78.08708 & 3720 & 0 & 25.267 & 0.3774 & 1 & $\begin{array}{c}919 \pm \\
26\end{array}$ & I & $0.917 \pm 0.026$ & I & $20414 \pm 1651$ & 592 & $19881 \pm 1314$ & 577 \\
\hline & $\begin{array}{c}\text { KXW- } \\
\text { Pan } \\
42^{* *}\end{array}$ & 36.33612 & 78.08694 & 3719 & 0 & 24.964 & 0.3796 & / & $\begin{array}{c}421 \pm \\
14\end{array}$ & I & $0.428 \pm 0.014$ & I & $10524 \pm 871$ & 361 & $10716 \pm 733$ & 368 \\
\hline To'SE & $\begin{array}{l}\text { KXW- } \\
\text { Pan 32* }\end{array}$ & 36.3 & 78.08686 & 3716 & 0 & 20.130 & 0.3464 & I & $\begin{array}{c}614 \pm \\
8\end{array}$ & I & $0.706 \pm 0.009$ & I & $16066 \pm 1232$ & 224 & $15737 \pm 959$ & 219 \\
\hline
\end{tabular}




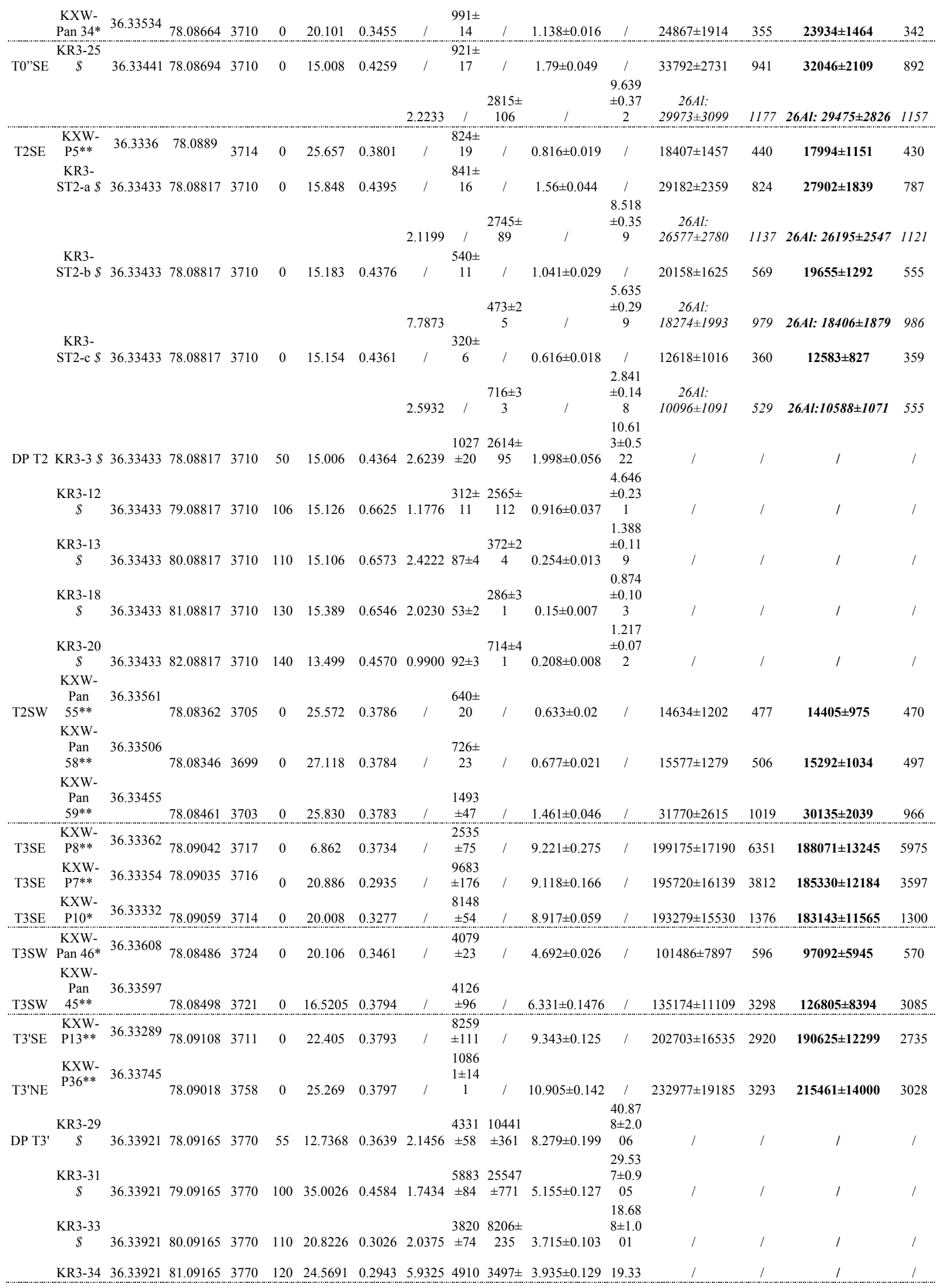




\begin{tabular}{|c|c|c|c|c|c|c|c|c|c|c|c|c|c|c|c|c|}
\hline & $\$$ & & & & & & & & \pm 128 & 112 & & $\begin{array}{c}5 \pm 0.6 \\
27\end{array}$ & & & & \\
\hline \multirow[t]{5}{*}{ T4SE } & $\begin{array}{l}\text { KXW- } \\
\text { P20* }\end{array}$ & 36.33283 & 78.09419 & 3740 & 0 & 20.372 & 0.3272 & ' & $\begin{array}{l}8540 \\
\pm 59\end{array}$ & l & $9.165 \pm 0.063$ & / & $195637 \pm 15738$ & 1455 & $185071 \pm 11701$ & 1371 \\
\hline & $\begin{array}{l}\text { KXW- } \\
\text { P17** }\end{array}$ & 36.33317 & 78.09257 & 3733 & 0 & 25.926 & 0.3796 & l & $\begin{array}{c}1231 \\
4 \pm 16 \\
5\end{array}$ & l & $12.046 \pm 0.161$ & / & $263775 \pm 21969$ & 3870 & $244714 \pm 16081$ & 3567 \\
\hline & $\begin{array}{l}\text { KXW- } \\
\text { P19** }\end{array}$ & 36.33271 & 78.09392 & 3736 & 0 & 25.267 & 0.3794 & / & $\begin{array}{c}1078 \\
3 \pm 14 \\
5\end{array}$ & l & $10.82 \pm 0.145$ & / & $234059 \pm 19299$ & 3411 & $216647 \pm 14103$ & 3139 \\
\hline & $\begin{array}{l}\text { KR3- } \\
\text { ST0L \$ }\end{array}$ & see map & see map & 3740 & 0 & 15.110 & 0.4376 & l & $\begin{array}{l}6192 \\
\pm 281\end{array}$ & l & $11.998 \pm 0.596$ & I & $222489 \pm 21572$ & 11912 & $206956 \pm 17113$ & 11022 \\
\hline & & & & & & & & 2.3834 & l & $\begin{array}{c}11867 \\
\pm 519\end{array}$ & 1 & $\begin{array}{c}43.57 \\
2 \pm 2.3 \\
76\end{array}$ & $\begin{array}{c}26 \mathrm{Al}: \\
135936 \pm 15988\end{array}$ & 8022 & $\begin{array}{c}\text { Al26: } \\
130901 \pm 14384\end{array}$ & 7702 \\
\hline \multirow[t]{7}{*}{ T4NE } & $\begin{array}{l}\text { KR3- } \\
\text { ST0a \$ }\end{array}$ & see map & see map & 3790 & 0 & 15.001 & 0.4363 & l & $\begin{array}{l}6927 \\
\pm 132\end{array}$ & / & $13.482 \pm 0.373$ & ' & $245894 \pm 21358$ & 7397 & $226885 \pm 15962$ & 6781 \\
\hline & & & & & & & & 2.3458 & l & $\begin{array}{c}19579 \\
\pm 511\end{array}$ & / & $\begin{array}{c}2 \pm 2.9 \\
34\end{array}$ & $\begin{array}{c}26 \mathrm{Al}: \\
223583 \pm 26172\end{array}$ & 10525 & $\begin{array}{c}\text { 26Al: } \\
213150 \pm 23039\end{array}$ & 9972 \\
\hline & $\begin{array}{c}\text { KXW- } \\
\text { P30* }\end{array}$ & 36.3356 & 78.09543 & 3786 & 0 & 20.265 & 0.3288 & / & $\begin{array}{l}9412 \\
\pm 65\end{array}$ & / & $10.206 \pm 0.07$ & / & $213090 \pm 17244$ & 1591 & $197897 \pm 12566$ & 1470 \\
\hline & $\begin{array}{l}\text { KXW- } \\
\text { P21** }\end{array}$ & 36.3347 & 78.09499 & 3771 & 0 & 24.5581 & 0.379 & / & $\begin{array}{l}7936 \\
\pm 108\end{array}$ & l & $8.185 \pm 0.1112$ & l & $173423 \pm 14011$ & 2497 & $161960 \pm 10354$ & 2323 \\
\hline & $\begin{array}{l}\text { KXW- } \\
\text { P23** }\end{array}$ & 36.33473 & 78.09479 & 3771 & 0 & 24.965 & 0.3797 & l & $\begin{array}{c}1208 \\
0 \pm 15 \\
7\end{array}$ & I & $12.276 \pm 0.159$ & / & $263360 \pm 21912$ & 3751 & $243802 \pm 15993$ & 3449 \\
\hline & $\begin{array}{l}\text { KXW- } \\
\text { P26** }\end{array}$ & 36.33454 & 78.09664 & 3748 & 0 & 26.150 & 0.3791 & I & $\begin{array}{l}9626 \\
\pm 127\end{array}$ & l & $9.326 \pm 0.123$ & l & $198063 \pm 16122$ & 2794 & $186999 \pm 12039$ & 2628 \\
\hline & $\begin{array}{l}\text { KXW- } \\
\text { Pan }\end{array}$ & 36.33884 & & & & & & & $\begin{array}{l}1161 \\
6 \pm 20\end{array}$ & & & & & & & \\
\hline \multirow[t]{3}{*}{ T4NW } & $52 * *$ & & 78.08673 & 3776 & 0 & 26.497 & 0.3796 & l & 8 & l & $11.119 \pm 0.199$ & l & $235556 \pm 19665$ & 4571 & $217467 \pm 14428$ & 4194 \\
\hline & $\begin{array}{c}\text { KXW- } \\
\text { Pan } \\
49^{* *}\end{array}$ & 36.33823 & 78.08601 & 3769 & 0 & 17.922 & 0.2912 & / & $\begin{array}{l}9467 \\
\pm 153\end{array}$ & l & $10.299 \pm 0.166$ & / & $215554 \pm 17790$ & 3754 & $200287 \pm 13112$ & 3470 \\
\hline & $\begin{array}{c}\text { KXW- } \\
\text { Pan } \\
51^{* *}\end{array}$ & 36.33906 & 78.08698 & 3778 & 0 & 18.749 & 0.2906 & l & $\begin{array}{l}8528 \\
\pm 140\end{array}$ & I & $8.856 \pm 0.145$ & l & $185259 \pm 15142$ & 3242 & $174411 \pm 11330$ & 3041 \\
\hline
\end{tabular}

Samples “*” and "**” were collected in 2011 and processed at Stanford University's cosmogenic facility and samples " $\$$ " were collected in 1995 and processed and measured at Center for Accelerator Mass Spectrometer (CAMS) at Lawrence Livermore National Laboratory (LLNL).

${ }^{10} \mathrm{Be} /{ }^{9} \mathrm{Be}$ ratios “*” were measured at CAMS at LLNL and ${ }^{10} \mathrm{Be} /{ }^{9} \mathrm{Be}$ ratios “**” measured at ASTER (CEREGE). Ages calculated with the CRONUS 3 calculator (Balco et al., 2008). Lm= Lal (1991)/Stone (2000) time-dependent production rate model. LSDn = Lifton et al. (2014) model ages discussed in text.

"See map" refers to Figure 3c, because no exact GPS location was measured in the field.

Shielding factor is 0.98; Sample density is $2.65 \mathrm{~g} / \mathrm{cm} 3$ (all samples are quartzite). Thickness was taken as $5 \mathrm{~cm}$. Standard used at CAMS for samples "*” is 07KNSTD with ${ }^{10} \mathrm{Be}$ isotope ratios $=2.85 \times 10-12$. For samples " $\$$ " standard is LLNL3000 with 10Be isotope rations $=3 \times 10-12$. KNSTD is the standard for Al samples. Standard used at ASTER is NIST SRM4325 (=NIST_27900) with ${ }^{10}$ Be isotope ratios $=2.79 \times 10-11$, equivalent to 07KNSTD.

ext. (int.) Uncert. = external (internal) uncertainty 
T2 Be

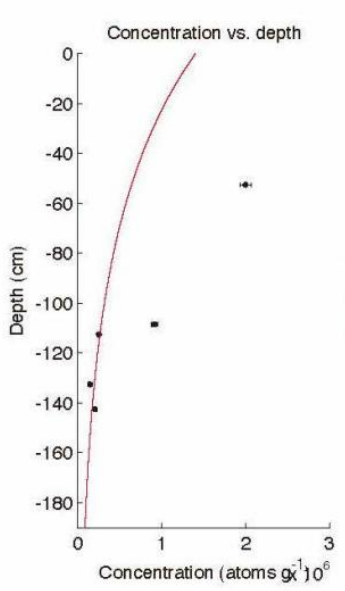

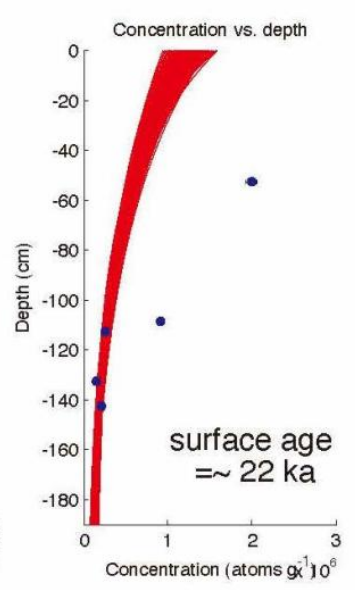

T2 Al
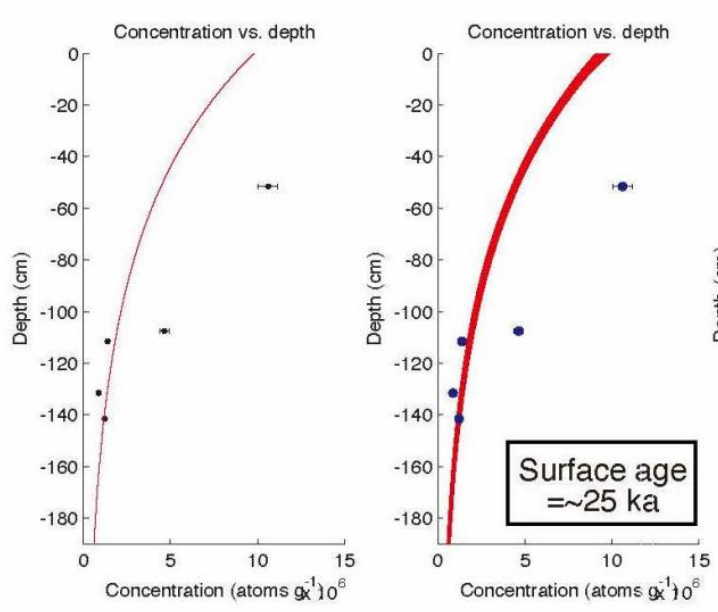

T3' Be
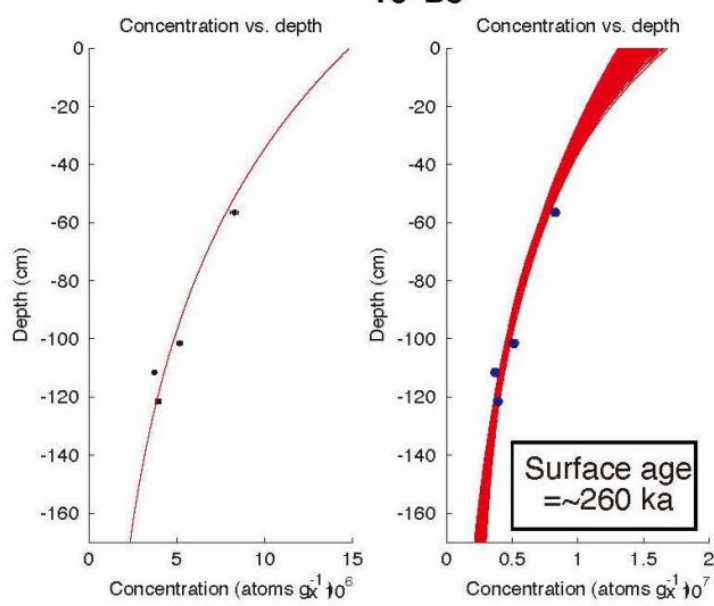

T2 Be (if 2 outliers rejected)
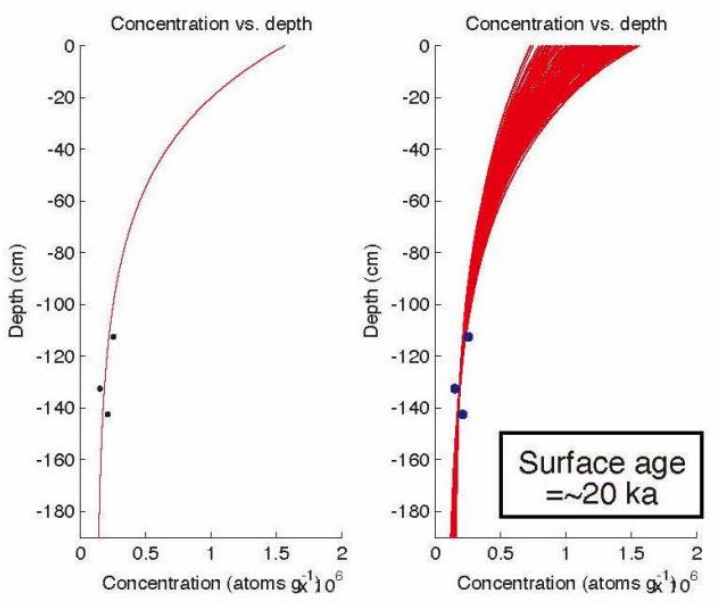

T2 Al (if 2 outliers rejected)
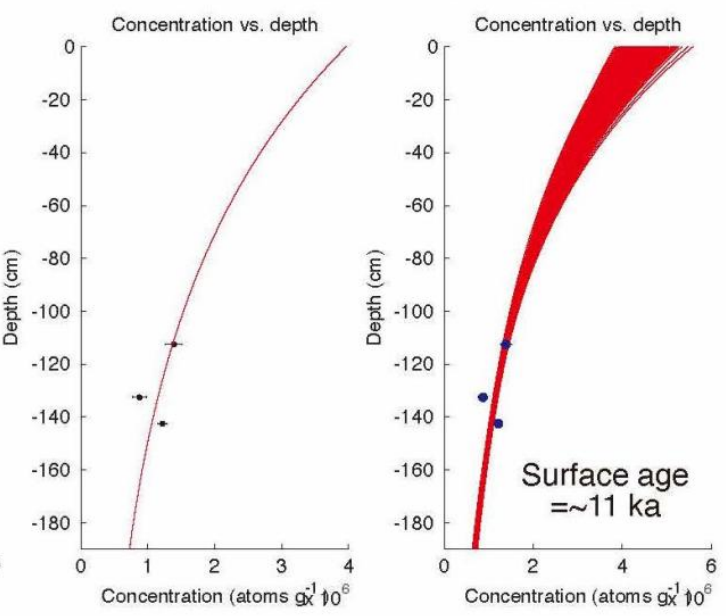

T3' Al
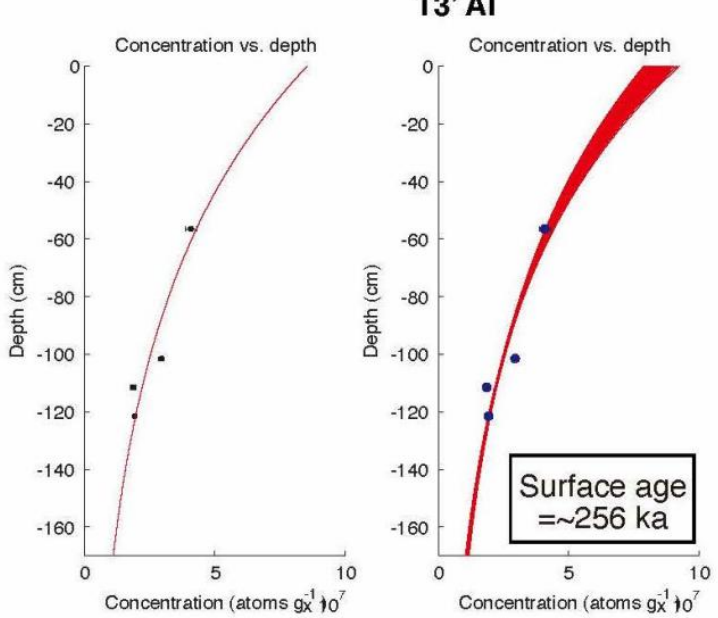

436 Figure 10. Depth profile (photos in Figs. S5 and S7) results using the Hidy et al. (2010)

437 software. Model surface ages consistent with ${ }^{10}$ Be and ${ }^{26}$ Al concentrations for T2 and T3' depth

438 profile samples, with or without outliers, are indicated. 


\section{Interpretation and discussion}

\subsection{Correlation of terrace ages with climate}

442 Whether a stream can transport sediments (hence emplace fans) or incise along its channel

443 (hence abandon terraces) is highly dependent on climate (e.g., Whipple and Tucker, 1999;

444 Mériaux et al., 2012). Typically, during glacial periods, stream power and sediment load are

445 limited, thus unfavorable to fan deposition. Glacier melting at the beginning of interglacials, due

446 to warmer climate, causes rapid increase of stream power and sediment transport, which in turn

447 promotes fill terrace aggradation and broad fan deposition. Conversely, it is well-established that

448 at the end of the warm and humid early Holocene Climatic Optimum (HCO, 10 to $\sim 5 \mathrm{ka}$ ),

449 coeval with lake high-stands on the Tibetan plateau (Gasse et al., 1991), a shift to drier climate

450 led to generally renewed river incision, terrace abandonment and lake level drop throughout

451 North-Africa, Eurasia and Tibet (e.g., Gasse et al., 1990; Avouac et al., 1996; Brown et al., 2003;

452 Li et al., 2005; Van Der Woerd et al., 2002).

453 The four main surface age groups we obtain, 206 $\pm 25 \mathrm{ka}$ for T4, 112 $\pm 21 \mathrm{ka}$ for T3-T3' (or $454 \sim 96 \mathrm{ka}$ for T3 and $\sim 113 \mathrm{ka}$ for T3'), 16 $\pm 3 \mathrm{ka}$ for T2 and 10 $\pm 2 \mathrm{ka}$ for T0s, correlate well with the 455 last four warm climatic periods at $\sim 200 \mathrm{ka}$ (MIS-7 interglacial), $\sim 115 \mathrm{ka}$ (Eemian interglacial), $456 \sim 16 \mathrm{ka}$ (post-Last Glacial Maximum, MIS-2, melting), and $\sim 10 \mathrm{ka}$ (Holocene interglacial) (green 457 bands in Fig. 9). The Eemian and Holocene ages we obtain at Taersa are similar, within 458 uncertainty, to the ${ }^{10} \mathrm{Be}$ ages $(\sim 110$ and $11 \mathrm{ka})$ found $18 \mathrm{~km}$ to the east, north of the Karakax 459 river by Peltzer et al. (2020) (their Site 4: large fan offsets first identified by Peltzer et al., 1989). 460 Likewise, within uncertainty, our youngest terrace ages are consistent with the OSL 
461 abandonment age $(\sim 9 \pm 1 \mathrm{ka})$ they found $\sim 10 \mathrm{~km}$ west of Taersa (Fig. 1b) for one offset terrace

462 ( 10 $\mathrm{m}$ above present fluvial channel, their Site 1) of a southern tributary of the Karakax river.

463 The Taersa site, however, uniquely preserves the oldest ( $210 \mathrm{ka})$ and highest ( $>110 \mathrm{~m}$ above

464 the Karakax river) conical fan surface dated thus far along the Karakax valley, and possibly for 465 now within the northern Tibet Plateau. Consequently, it is possibly also the only site where the 466 largest horizontal and vertical cumulative offsets are preserved along the KXF.

\subsection{Fault slip rates since $\sim 210 \mathrm{ka}$}

Combining alluvial surface abandonment ages and riser offsets provides bounds on slip rates over a $\sim 210$ ka-long timescale. Matching the T4 abandonment age (206 $\pm 25 \mathrm{ka})$ with the total

471 offsets of the current T4 southeastern limit and the inferred western T4 riser top ( $\sim 500 \pm 50$ and $472496 \pm 24 \mathrm{~m}$, respectively) yields $2.4(+0.4 /-0.3) \mathrm{mm} / \mathrm{yr}$ (Figs. 3c, 7, 11a and Table 2). Combining 473 the T4/T3' current riser base offset $(255 \pm 10 \mathrm{~m})$ with the inferred oldest age of T3'east (127 $\pm 8 \mathrm{ka}$ 474 based on that on T3west) yields a minimum rate of $2.0(+0.2 /-0.1) \mathrm{mm} / \mathrm{yr}$. Taking the inferred 475 youngest age of T3east ( $97 \pm 6 \mathrm{ka}$ based on that on T3west) with the current offset $(255 \pm 5 \mathrm{~m})$ of 476 the T3'/T3 riser base yields $2.6 \pm 0.2 \mathrm{~mm} / \mathrm{yr}$. Matching the offset of the current T3/T2 western 477 riser base $(200 \pm 20 \mathrm{~m})$ with the inferred youngest $97 \pm 6 \mathrm{ka}$ age of T3 yields $2.1(+0.3 /-0.2) \mathrm{mm} / \mathrm{yr}$ 478 (Figs. 3c, 11a, S6 and Table 2). Lastly, we take the age of the $22.9 \pm 1.5 \mathrm{~m}$ offset of the base of 479 the T2/T0" riser (Figs. 3e, S4 and S6), that necessarily postdates the total incision (10 m) of T2 480 (abandoned after $16 \pm 3 \mathrm{ka}$ ) by the Holocene Taersa tributary, to be $10 \pm 2 \mathrm{ka}$, which is consistent 481 with a slip rate of $2.3(+0.6 /-0.4) \mathrm{mm} / \mathrm{yr}$ (Figs. 11a,b, S6 and Table 2). The normal throw 482 component across the fault at Taersa may also be estimated using the vertical offsets of $\mathrm{T} 4$ and 483 T3' (Fig. 5c). The $\sim 28 \mathrm{~m}$ offset of T4 implies a throw rate of $0.14 \pm 0.2 \mathrm{~mm} / \mathrm{yr}$, while the 12 and 
$48410 \mathrm{~m}$ vertical offsets of T3' and T3, respectively, are consistent with a throw rate of $0.1 \pm 0.01$

$485 \mathrm{~mm} / \mathrm{yr}$.

486

487 Table 2. Summary of offsets, ages and slip rates at Taersa.

\begin{tabular}{|c|c|c|c|}
\hline & Offsets $(\mathrm{m})$ & Ages $(\mathrm{ka})$ & Slip rate $(\mathrm{mm} / \mathrm{yr})$ \\
\hline T4 southeastern limit & $500 \pm 50$ & $206 \pm 25$ & $2.4(+0.4 /-0.3)$ \\
\hline Original T4 riser at incision onset & $496 \pm 24$ & $206 \pm 25$ & $2.4(+0.4 /-0.3)$ \\
\hline T4/T3' current base & $255 \pm 10$ & $127 \pm 8$ & $2.0(+0.2 /-0.1)$ \\
\hline T3'/T3 current base & $255 \pm 5$ & $97 \pm 6$ & $2.6 \pm 0.2$ \\
\hline T3/T2 current base & $200 \pm 20$ & $97 \pm 6$ & $2.1(+0.3 / 0.2)$ \\
\hline T2/T0" current base & $22.9 \pm 1.5$ & $10 \pm 2$ & $2.3(+0.6 /-0.4)$ \\
\hline T0"/T0' & $17.8 \pm 1.5$ & $<10 \pm 2$ & $2-3$ \\
\hline T0'/T0 & $12.8 \pm 2.5$ & $<10 \pm 2$ & $2-3$ \\
\hline T0/river bed & $5.9 \pm 0.5$ & $1882 \mathrm{AD}$ & $\mathrm{n} / \mathrm{a}$ \\
\hline
\end{tabular}




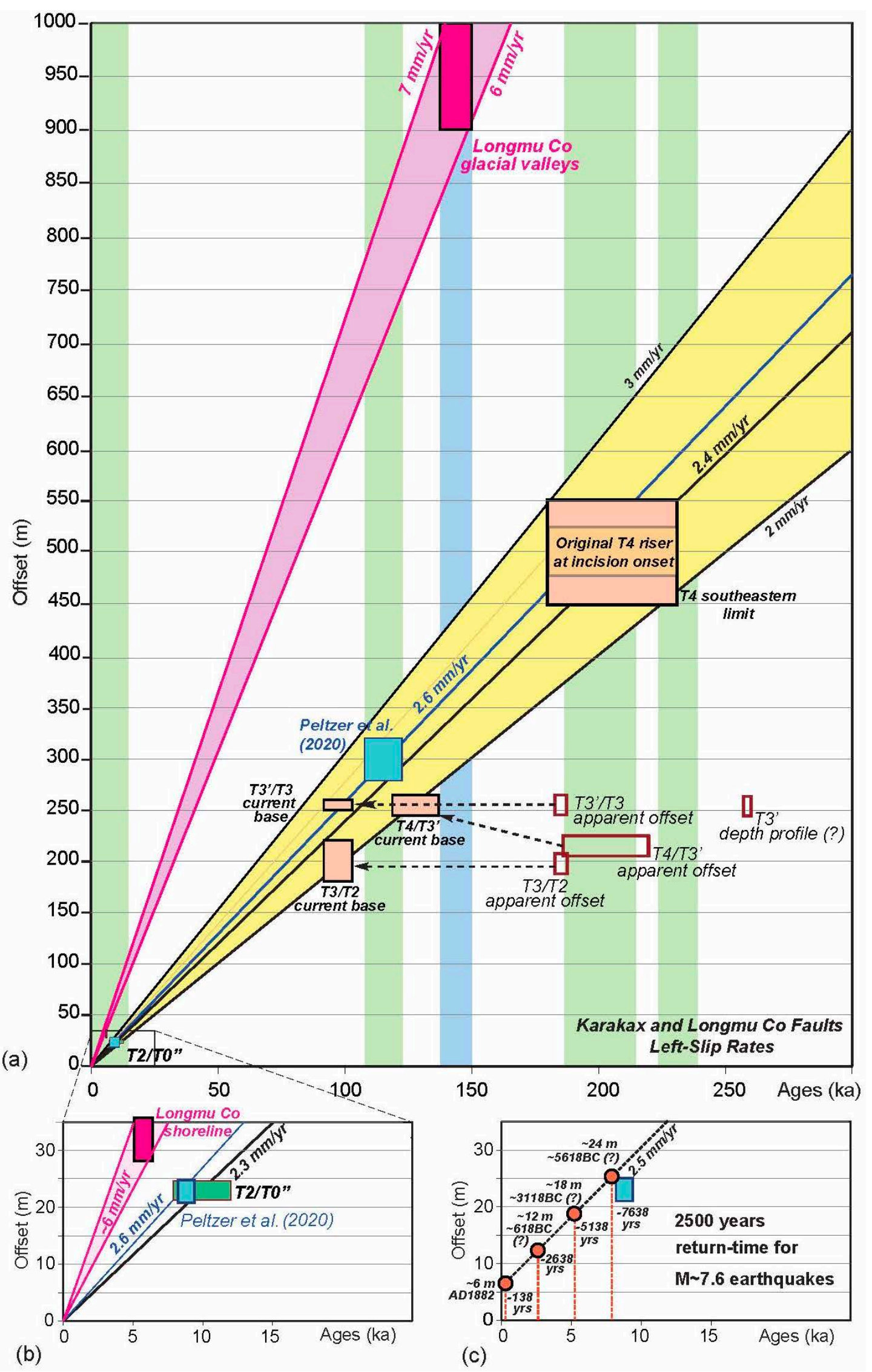

(b)

(c) 
Figure 11. Slip rates on Karakax and Longmu Co faults. (a) Late Quaternary slip rates derived from offset/age relationships. Dashed black arrows indicate most plausible shifts of offset and ages of risers east of Taersa tributary based on T3 ages west of tributary (see text for details).

493 Green bands are interglacial periods as in Figure 9, blue band is coldest glacial within MIS-6.

494 See text for details. (b) Zoom on youngest terrace age range, including Peltzer et al. (2020) result. (c) Inferred large earthquakes return times consistent with simplified characteristic coseismic slip $(\sim 6 \mathrm{~m})$ and constant Holocene $\sim 2.5 \mathrm{~mm} / \mathrm{yr}$ slip rate. $\mathrm{mm} / \mathrm{yr}$, hence a most likely long-term average between 2 and $3 \mathrm{~mm} / \mathrm{yr}$ (Fig. 11a). Within $\sim 20 \%$ uncertainty ( 0.4 to $0.6 \mathrm{~mm} / \mathrm{yr}$ ), these rates appear to have been constant over a much longer

501 timescale $(\sim 210 \mathrm{ka}), \sim 100 \mathrm{ka}$ older than that documented so far. They compare well with the $502 \quad 2.6 \pm 0.5 \mathrm{~mm} / \mathrm{yr}$ rate recently determined by Peltzer et al. (2020) in the last $\sim 115 \mathrm{ka}$. Locally, the total Taersa long-term rates include a vertical component $(\sim 0.1 \mathrm{~mm} / \mathrm{yr})$ that absorbs some

504 cumulative displacement. Additionally, faulting along the southern side of the pull-apart sag within the Karakax valley (Fig. 2) may contribute to increase slightly the total Taersa slip rate.

Such consistent, $\sim 2.5 \mathrm{~mm} / \mathrm{yr}$ average rate values at three sites over a $\sim 35 \mathrm{~km}$-long stretch of the fault suggest that previous estimates of rates 2 to 3 times faster $(6-9 \mathrm{~mm} / \mathrm{yr})$, may have been biased. Li et al.'s (2012) estimate (6-7 mm/yr) was based on just one ${ }^{14} \mathrm{C}$ date $(975-1020 \mathrm{AD})$ in 509 one trench west of Taersa with no in situ horizontal offset measurement (Fig. 2). Gong et al.'s 510 (2017) rate $(7.8 \pm 1.6 \mathrm{~mm} / \mathrm{yr})$ was derived from the OSL dating of six, reportedly fluvial, sand 511 samples $(39.7 \pm 2.5 \mathrm{ka}$ for T4 [their T5], 28.5 $\pm 1.7 \mathrm{ka}$ for T3’ [their T4], 21.2 $\pm 1.2 \mathrm{ka}$ for T3 and $51214.5 \pm 1.0 \mathrm{ka}$ for T2) retrieved from the very top of unstable, south-facing risers, likely still 513 retreating and affected by steady, long-term rejuvenation due to ongoing erosion by the Karakax 514 river (Fig. 8a). In fact, more importantly, since the depth of these OSL samples is very shallow 
515 (15-45 cm, Gong et al., 2017), and their ages much younger than those we obtain on all the

516 relevant surfaces (Fig. 9), we suspect that the deposits they dated may include loess windblown

517 atop the terrace surfaces much later than their fluvial abandonment ages.

518

In the last 150 years, seven large $(M \geq 7)$ earthquakes have struck the broad region

522 surrounding the West Kunlun range and western branches of the Altyn Tagh fault (ATF) (Figs. 1

523 and 13) (SBX, 1997). The most recent $\left(\mathrm{M}_{\mathrm{w}} 6.9,2014\right.$ and $\mathrm{M}_{\mathrm{w}} 7.2,2008$ Yutian earthquakes)

524 ruptured the Ashikule left-lateral fault (Li et al., 2016) and the West Pingding normal fault (e.g., 525 Xu et al., 2013), within the transition zone between the ATF and the Longmu-Gozha Co fault 526 (LGCF). Another event $\left(M_{s} 6.9\right.$ in 1996) ruptured a poorly studied, probably $\sim$ EW-striking fault 527 within the Tianshuihai block, with a debated left-lateral or thrust mechanism (USGS; Ma et al., 528 1997). One century ago, in 1924, two events with estimated magnitudes of 7.2 and 7.5 (Chen, 529 1988) likely ruptured segments or splays of the western ATF east of Minfeng. Even earlier on, in 5301882 and 1889 , two large earthquakes are reported to have been strongly felt in Hotan and 531 Yecheng, respectively (Nikonov, 1975; Ma, 1989; Avouac and Peltzer, 1993). Since little is

532 known about these two events, however, doubts have been raised on their existence or location 533 (Yang et al., 1991).

534 Yet, during our field work across the region, we found only one large, fresh surface rupture 535 along faults in the West Kunlun range south of Hotan and Yecheng (Fig. 12). In the field and on 536 high-resolution satellite images, this rupture (yellow swath in Fig. 1b) may be followed 537 continuously for $\sim 150 \mathrm{~km}$, from $\sim 77.5^{\circ} \mathrm{E}$ to $79^{\circ} \mathrm{E}$. Where the fault is single-stranded, field 
538 measurements imply an average left-lateral co-seismic displacement of $6 \pm 1 \mathrm{~m}$ (Li et al., 2012).

539 The facts that this rupture displays well-preserved, $\sim 1.5 \mathrm{~m}$-high, free-faces and en-echelon mole

540 tracks across the Sanshili and other fans (Li et al., 2012), that it affects the most recent terraces,

541 and that it is still visible across some of the floodplains of the Karakax tributaries (Fig. 12), are in

542 keeping with the inference that it is less than 200 years old. The measured rupture length and slip

543 amount are consistent with a magnitude M7.6 $(\mathrm{M}=5.08+1.16 * \log [$ surface rupture length $=150 \mathrm{~km}$ ]

544 or $\mathrm{M}=6.93+0.82 * \log [$ average displacement $=6 \mathrm{~m}]$, Wells and Coppersmith, 1994). Hence, as

545 inferred by Avouac and Peltzer (1993), we conclude that this rupture is most likely that of the

5461882 Hotan earthquake (Fig. 1b). 


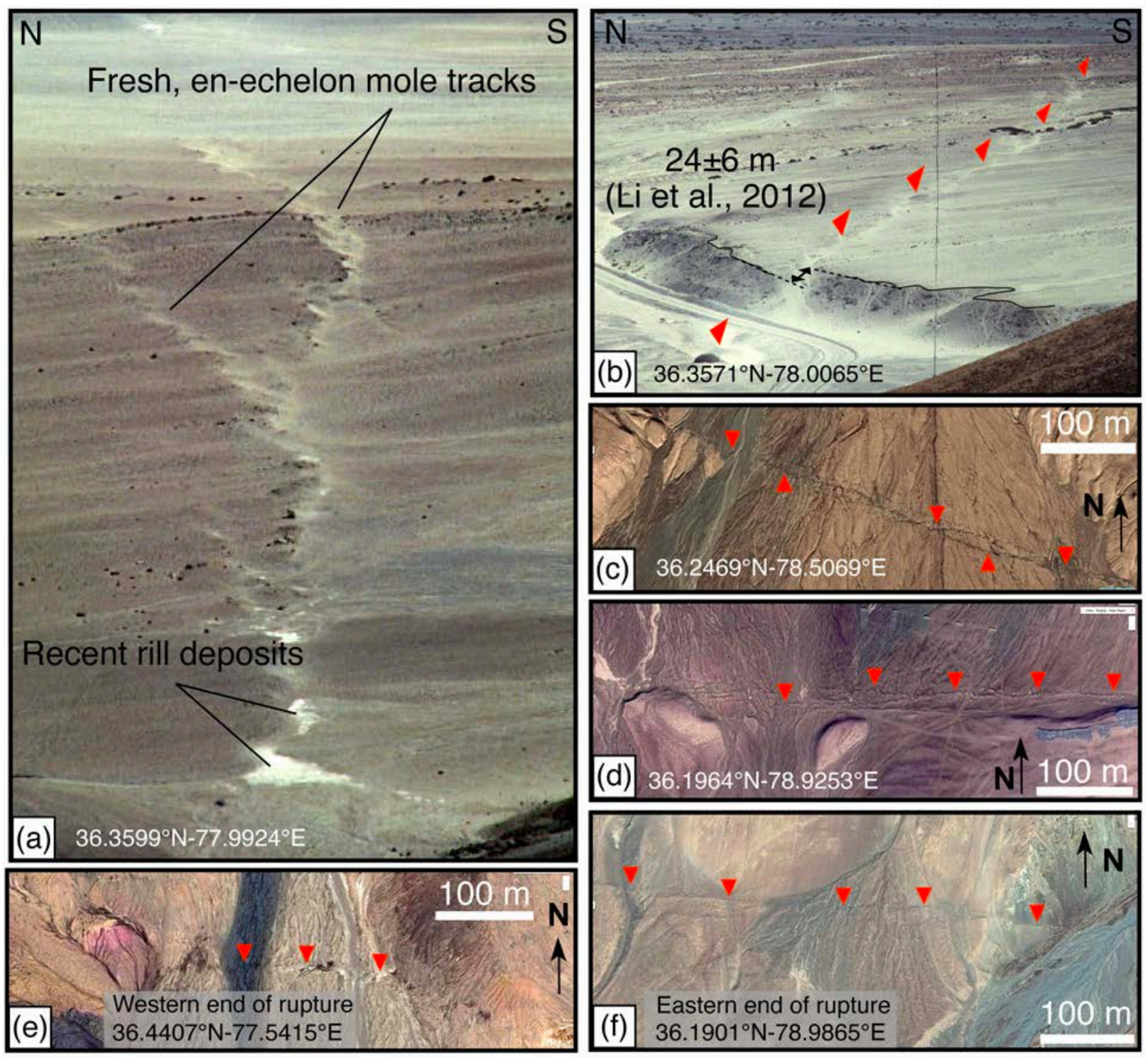

$36.1901^{\circ} \mathrm{N}-78.9865^{\circ} \mathrm{E}$

549 Figure 12. Fresh surface rupture of 1882 earthquake (see image locations in Fig. 1b). (a)

550 Field photograph (P. Tapponnier, 1989) of en-echelon, right-stepping scarps across fan south of

551 Karakax river, west of Sanshili. Note slight vertical offset north of rupture and fresh white

552 pluvial deposits dammed by scarp. (b) Field photograph of offset, western riser of Sanshili fan

553 ( 24 $16 \mathrm{~m})$ and fresh surface rupture across fan surface. Note again slight vertical offset north of

554 fault trace. (c and d) Maxar satellite images of fresh seismic rupture across recent Karakax

555 tributary alluvial surfaces and active seasonal streams. (e and f) Deep open cracks close to

556 western and eastern terminations of $\sim 150 \mathrm{~km}$-long, 1882 surface rupture, respectively. 
Finally, the epicenters of one historical event and one recent earthquake both lie in the SW

559 Tarim basin, just north of the West Kunlun range. The 2015, Mw 6.4 Pishan earthquake ruptured

560 a blind, south-dipping thrust west of Hotan (Fig. 1a) (e.g., Lu et al., 2016; Wen et al., 2016;

561 Guilbaud et al., 2017; Laborde et al., 2019). The poorly documented, possibly larger, 1889 event,

562 tentatively located near Yecheng, might also have ruptured a blind thrust in the Kunlun foreland,

563 south of the emergent, active Mazartagh thrust ramp (Fig. 13a).

564 The large 1882 Karakax surface break appears to be the latest in a sequence of similar 565 ruptures with comparable amounts of co-seismic slip. Previous field measurements (Li et al., 566 2012) documented cumulative offset amounts of $\sim 12, \sim 18$ and $\sim 24 \mathrm{~m}$ across four young fluvial

567 fans along the central $\sim 50 \mathrm{~km}$ of the rupture. At Taersa, our new Matlab measurements confirm 568 values of $\sim 6, \sim 13, \sim 18$ and $\sim 23$ m across the lowermost, Holocene (10 $\pm 2 \mathrm{ka}$ ), alluvial terraces 569 (Fig. 3e). The $\sim 2.5 \pm 0.5 \mathrm{~mm} / \mathrm{yr}$ slip rate at this site would thus be consistent with characteristic 570 slip $(\sim 6 \mathrm{~m})$ event's return times of $\sim 2500 \pm 500$ years (Fig. 11c). Note that such long recurrence 571 times preclude the use of historical records to assess seismic hazard on the fault. The rare 572 preservation of four cumulative co-seismic offsets over the entire Holocene period yields a 573 characteristic slip record that would be hard to obtain from trenching, even where sedimentary 574 records reach back that long (e.g., Daëron et al., 2007). geodetically across the West Kunlun range during the last $\sim 20$ years: e.g., $7 \pm 3 \mathrm{~mm} / \mathrm{yr}$ (GPS,

579 Shen et al., 2001), $5 \pm 5$ mm/yr (Interferometric Synthetic Aperture Radar [InSAR], Wright et al., 
2004). As discussed below, this may be a corollary consequence of the complex crustal deformation and faulting geometry across the western tip of Tibet (Figs. $1 \mathrm{a}$ and 13a). et al., 1989, Ding et al., 2004) with the likely onset age ( $\geq 24 \mathrm{Ma})$ of rapid sedimentation in the

584 Tarim basin's Kunlun foreland and of sustained tectonic uplift along the West Kunlun range (e.g., 585 Matte et al., 1996; Sobel and Dumitru, 1997; Métivier et al., 1999; Cao et al., 2015), would yield 586 a long-term slip rate of $\leq 3.3 \mathrm{~mm} / \mathrm{yr}$, consistent, within uncertainties, with the average late 587 Quaternary rate we document here. The similar $\sim 80 \mathrm{~km}$ offset of the neighboring Karakax and 588 Yurungkax, two comparably large rivers crossing the KXF across nearly impassable 589 gorges/canyons (Fig. 1a), have long been described and clearly attributed to sinistral movement 590 along the fault (e.g., Gaudemer et al., 1989; Ding et al., 2004). The two river floodplains are, and 591 must have long been, captive within their deeply incised passages across mountain ranges that 592 are now 6000 to 7000 m-high. That the highest Kunlun peaks NW and SE of the offset Karakax 593 river are $\sim 6300$ and $\sim 6698 \mathrm{~m}$-high, i.e., $\sim 2600 \mathrm{~m}$ and $\sim 3000 \mathrm{~m}$ above the present valley floor 594 ( $\sim 3700 \mathrm{~m})$, respectively (Fig. 1b), requires that these large offsets be nearly coeval with the onset 595 of mountain uplift.

596 The $\sim 24 \mathrm{Ma}, \sim 210 \mathrm{ka}, \sim 110 \mathrm{ka}$, and $\sim 10 \mathrm{ka}$ slip rates along the Karakax splay of the ATF 597 would thus all fall between 2 and $3.3 \mathrm{~mm} / \mathrm{yr}$, in keeping with a long ( 2500 years) return time 598 for $\mathrm{M} \sim 7.6$ earthquakes and a total, post-early Miocene offset of $\sim 80 \mathrm{~km}$. That relatively slow rate 599 is surprising given the clear, continuous surface trace, the fairly large co-seismic and geological 600 offsets, the prominent $\sim 150 \mathrm{~km}$-long 1882 surface rupture, and the exceptionally well-preserved 601 geomorphic expression of the fault (Fig. 12). Peltzer et al. (2020) suggested that variable slip or 602 erosion rates might account for the non-linear relationship between progressive scarp 
603 degradation and cumulative displacement along the fault. Our results tend to support the latter,

604 although complexities in the fault trace involving pull-apart sags and releasing bends, hence sub-

605 parallel surface strands, in part hidden within the fast-evolving, modern Karakax river floodplain,

606 likely play a significant role.

607

\section{$608 \quad 5.5$ Left-lateral slip rate along the Longmu Co fault}

609 While we do not provide here more local dates along the Longmu Co fault (southern branch

610 of the LGCF) south of the Sumxi-Longmu Lakes, the offsets shown in Figure 4 ( $32 \pm 4$ and

$611950 \pm 50 \mathrm{~m})$ are newly-derived from a dedicated, small-scale UAV survey and from recent (2021)

612 high-resolution "Maxar Technology" satellite images, respectively. Age constraints for these two

613 different cumulative offsets may be suitably deduced from reliable, published, local and regional

614 dating by Gasse et al. (1991), Avouac et al. (1996), and Amidon et al. (2013). The twin Sumxi

615 and Longmu Lakes were long-connected as a unique, large lake with maximum water heights at

616 least $\sim 230 \mathrm{~m}$ above present level (Avouac et al., 1996) during the early HCO ( $\sim 10$ to $\sim 5 \mathrm{ka}$,

617 Gasse et al., 1991). The $32 \pm 4 \mathrm{~m}$ left-lateral offset of the topmost shoreline of the paleo-Sumxi-

618 Longmu Lake must post-date the abandonment of that shoreline as the lake level rapidly dropped

619 down at the end of the HCO (6-5.5 ka, Avouac et al., 1996). This implies a slip rate on the

620 Longmu Co fault of $5.6 \pm 0.9 \mathrm{~mm} / \mathrm{yr}$ (Fig. 11b).

621 The larger offsets $(\sim 950 \pm 50 \mathrm{~m})$ of the narrow glacial streams, now captive within the

622 abandoned glacial valleys crossing the fault south of the lakes, likely post-date the MIS-6 glacial

623 maximum ( 180-140 ka, Fig. 9), after which incision began, a timing in keeping with the age of

624 the oldest, recessional frontal moraine $\left(34.414^{\circ} \mathrm{N}-80.046^{\circ} \mathrm{E}\right)$ dated at $123 \pm 5$ ka by Amidon et al.

625 (2013). Note that this moraine is located only $\sim 21 \mathrm{~km}$ southwest of the offset shoreline site (Fig. 
626 4) and $\sim 8 \mathrm{~km}$ due south of the westernmost abandoned shorelines of Sumxi-Longmu Lake

627 (Avouac et al., 1996). Assuming that the glacial valley offsets post-date glacial retreat (e.g.,

628 Chevalier et al., 2005), between $\sim 150$ and $140 \mathrm{ka}$, their $950 \pm 50 \mathrm{~m}$ average sinistral offset would

629 imply a slip rate of $6.5 \pm 0.4 \mathrm{~mm} / \mathrm{yr}$ (Fig. 11a). We conclude that the slip rate along the Longmu

630 Co fault may be significantly faster than the value proposed by Chevalier et al. (2017) $(<3 \mathrm{~mm} / \mathrm{yr}$

631 at a site located $\sim 15 \mathrm{~km}$ west of the offset shoreline above), that may have been biased by the

632 ages of cobbles transported downstream by post-glacial reworking of upstream moraine deposits.

633 Note that the two rate values derived here along the central Longmu Co fault south of Lake

634 Sumxi are within the range of those inferred at various timescales by Raterman et al. (2007).

\subsection{Large-scale slip partitioning, triple junction kinematics and crustal} block tectonics across western Tibet

Earlier studies along the ATF suggested Quaternary slip rates of up to $20-30 \mathrm{~mm} / \mathrm{yr}$ (e.g., Molnar et al., 1987; Molnar and Lyon-Caen, 1989; Peltzer et al., 1989; Mériaux et al., 2004, 2005; Ryerson et al., 2006), the latter three at specific field sampling sites along the central and eastern ATF. While local rates $\geq 20 \mathrm{~mm} / \mathrm{yr}$ have been disputed, rates between $\sim 10$ and $15 \mathrm{~mm} / \mathrm{yr}$

642 along the fault from $\sim 84$ to $93^{\circ} \mathrm{E}$ are now well-established over different timescales (e.g., Gold et 643 al., 2011; Mériaux et al., 2012; Daout et al., 2018 and references therein). How rates $\geq 10 \mathrm{~mm} / \mathrm{yr}$ 644 on the central ATF decrease to only 2-3 mm/yr in the Karakax valley must be accounted for. The 645 most plausible reason is the westward increasing complexity of the ATF system. While relatively 646 linear, although segmented into parallel strands by releasing and restraining bends east of $84^{\circ} \mathrm{E}$, 647 the fault partitions westwards into distinct branches separating rising mountains from broad 648 basins (Figs. 1 a and 13a). Whereas it is essential to assess crustal kinematics across western 
649 Tibet, such splitting into splays with strike-slip, thrust or normal components remains to be 650 accurately quantified.

651 The central ATF divides into two main faults (KXF and LGCF) at the Uzatagh triple junction $652\left(83^{\circ} \mathrm{E}\right.$, Fig. 13a). Near that junction, where the strike of the KXF starts veering northwards by $653 \sim 40^{\circ}$, the sub-parallel Pishan-Kashitashi thrust, which raises the West Kunlun range to maximum 654 elevations of $\sim 6000-6700 \mathrm{~m}$, also terminates. A similar $\sim 40^{\circ}$ clockwise turn occurs near $81^{\circ} \mathrm{E}$ in 655 the Tarim foreland, between the emergent Minfeng-Cherchen sliver- and Mazar Tagh thrusts, 656 that parallel the ATF and KXF, respectively. We thus interpret the $\sim$ NE-striking, dominantly 657 normal, Qira fault zone (Avouac and Peltzer, 1993), to merge with both the Minfeng-Cherchen 658 sliver thrust and a $\sim$ NS-striking ramp bounding the eastern side of the Mazar Tagh thrust sheet. 659 Such a connection, near Qira, may be regarded as another triple junction (Damagou junction, 660 Fig. 13a). Southwest of Uzatagh, the ATF splits into a complex pull-apart system with oblique 661 sinistral/normal branches that merge back again southwestwards into the left-stepping LGCF 662 (Figs. 1 a and 13a). While the M 7, 2008 and 2014 Yutian earthquakes ruptured the 663 northwestern (West Pingding and Ashikule-Xor Kol) branches of that system, no large event has 664 been recorded yet along the southeastern branch, although it follows a deep, active rift between 665 the highest mountains (>6900-7100 m) of the West Kunlun range (Fig. 13a). Finally, farther SW, 666 the Longmu Co fault merges with the southern and northern Karakorum faults at the Angmong 667 triple junction, which also marks the southern termination of the high Karakorum range (Fig. 668 13a), where $>40 \mathrm{~km}$ of post-Miocene crustal heave has occurred (Van Buer et al., 2015). 


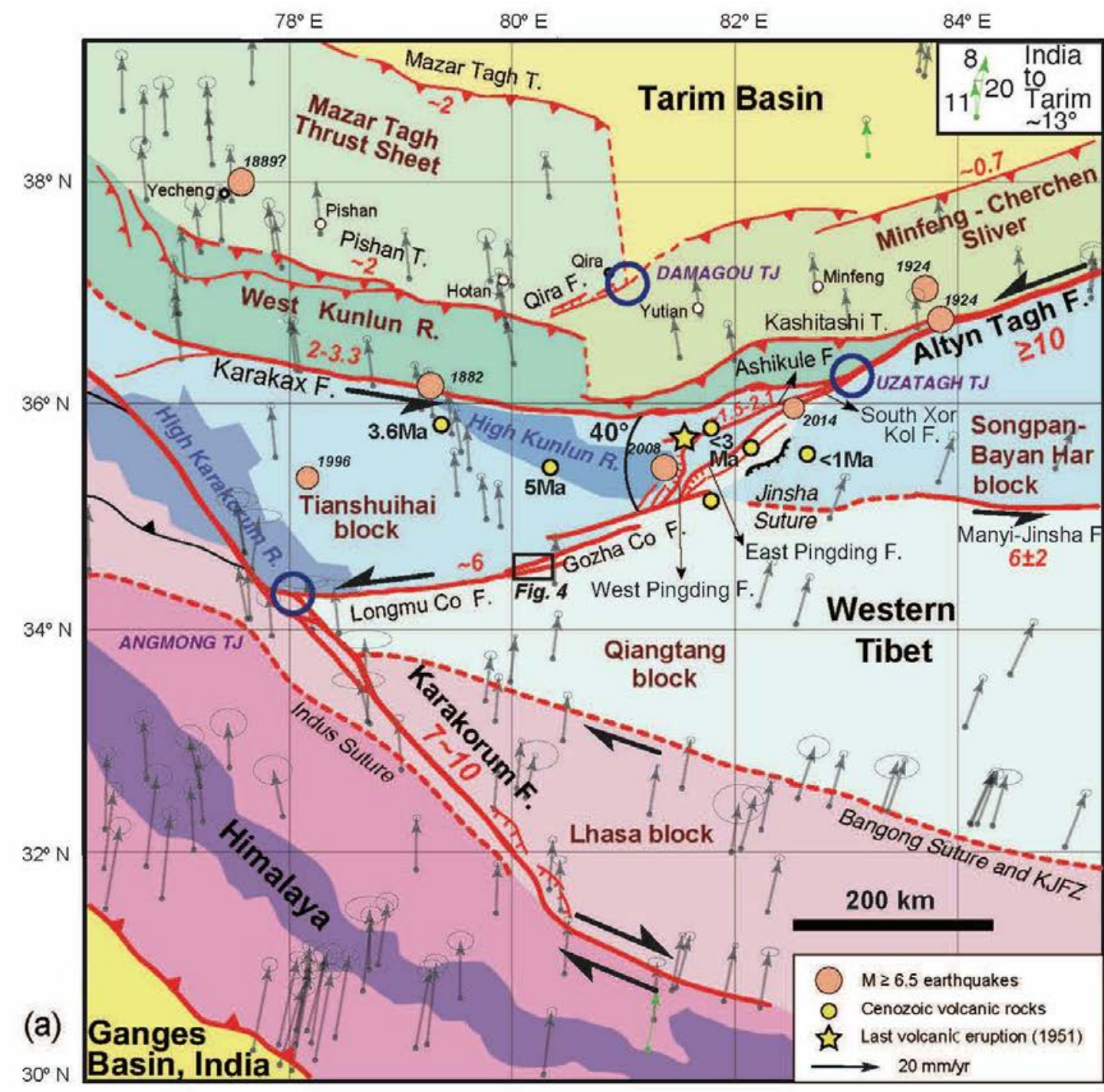

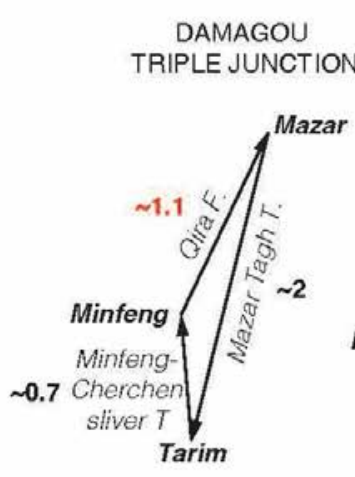

(b)

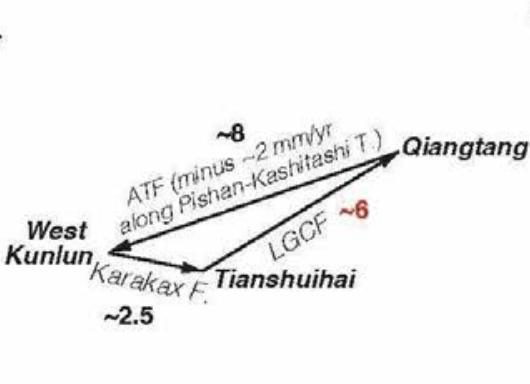

(c)

UZATAGH TRIPLE JUNCTION

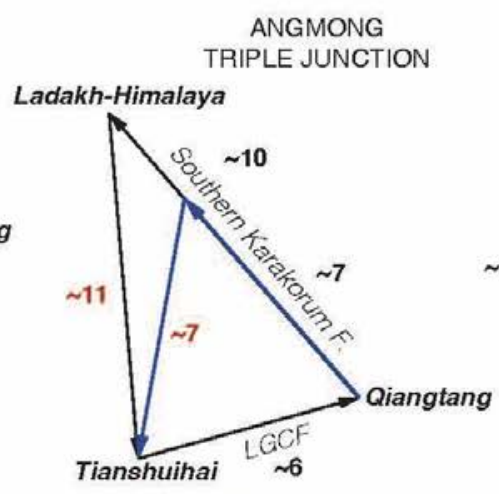

(d)

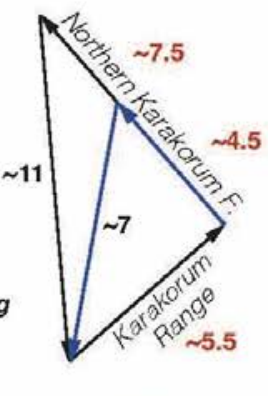

(e)

Figure 13. Block tectonics model consistent with updated fault slip rates across western Tibet. (a)

672 Summary of late Quaternary slip rates (numbers in red, in $\mathrm{mm} / \mathrm{yr}$ ) along main active faults ( $F$., 
673 red lines) and thrusts (T., red lines with teeth) separating crustal blocks between India and 674 Tarim (colored, after Wittlinger et al., 2004), with GPS vectors (small arrows) relative to stable 675 Eurasia (Wang and Shen, 2020). Large blue circles are three main triple junctions (TJ). Dark 676 blue/purple polygons highlight the highest topography along the Kunlun, Karakorum and 677 Himalayan ranges (R.). Small black box along LGCF indicates location of Figure 4. (b-e) 678 Triangular diagrams consistent with vector sums of late Quaternary slip rates along faults 679 separating blocks around triple junctions (red numbers are predicted rates; see discussion in 680 text). Top right inset is triangular diagram between current GPS vectors (green) just north of 681 Himalaya and in Tarim basin.

While few long-term slip rates are well-constrained except along the ATF-KXF and 684 Karakorum faults, InSAR measurements now reveal $\sim 0.7 \mathrm{~mm} / \mathrm{yr}$ of $\sim \mathrm{NS}$ shortening across the 685 Minfeng-Cherchen thrust and $6 \pm 2 \mathrm{~mm} / \mathrm{yr}$ of $\sim \mathrm{EW}$ sinistral motion along the western ManyiJinsha fault (Daout et al., 2018) (Fig. 13a). Field studies imply $\sim$ NS shortening rates of $\sim 2-2.5$ 687 and $\sim 1.5-2.5 \mathrm{~mm} / \mathrm{yr}$ across the Pishan and Mazar Tagh thrusts, respectively (Guilbaud et al., 688 2017; Laborde et al., 2019). If assumed constant since shortening began in the West Kunlun range ( $\sim 24 \mathrm{Ma})$, the sum of the latter rates $(\sim 3.5-5 \mathrm{~mm} / \mathrm{yr})$ would be consistent with subduction 690 of the Tarim lithospheric mantle to a depth of $\sim 200 \mathrm{~km}(88-125 \mathrm{~km}$ beneath the $\sim 90 \mathrm{~km}$ depth of 691 the west Tibetan Moho) (Lyon-Caen and Molnar, 1984; Wittlinger et al., 2004), in classic plate 692 tectonic behavior, coherent with young volcanism south of the West Kunlun range (small yellow 693 circles in Fig. 13a). Lastly, along the Ashikule fault, cosmogenic dating of terrace offsets 694 suggests rates of $\sim 1.5-2.1 \mathrm{~mm} / \mathrm{yr}$ (Pan et al., 2015) (Fig. 13a).

695 Kinematic triangular diagrams (Fig. 13b-e) fitting the vector sums of rates along the faults 696 that separate the seven west-Tibetan blocks (Tarim, Mazar, Minfeng, Qiangtang, West Kunlun, 697 Tianshuihai, Ladakh-Himalaya; color-coded in Fig. 13a), which appear to take up much more 698 seismic strain than does internal deformation, clearly support block tectonics (e.g., Meyer et al., 
1998; Raterman et al., 2007). Specifically, at the Damagou junction, divergent thrusting on the Mazar Tagh and Minfeng thrusts results in $\sim 1.1 \mathrm{~mm} / \mathrm{yr}$ of $\sim$ NNE extension along the Qira fault zone (Fig. 13b). The decrease in sinistral rate between the ATF and KXF is consistent with transfer, at the Uzatagh junction, of $\sim 6 \mathrm{~mm} / \mathrm{yr}$ of slip along the LGCF (Fig. 13c) in a direction enabling extension along the eastern boundary of the West Kunlun range. That rate is consistent

704 with both the $32 \pm 4 \mathrm{~m}$ offset of the Sumxi-Longmu Lake topmost shoreline, abandoned $\sim 6-5.5 \mathrm{ka}$ 705 ago (Gasse et al., 1991; Avouac et al., 1996) and the larger offsets $(950 \pm 50 \mathrm{~m})$ of Eemian $(123 \pm 5$ 706 ka, Amidon et al., 2013) glacial valleys (Fig. 4). Finally, the vector sum of rates along the 707 southern Karakorum ( $\sim 10 \mathrm{~mm} / \mathrm{yr}$, Chevalier et al., 2005$)$ and LGCF $(\sim 6 \mathrm{~mm} / \mathrm{yr})$ predicts $\sim 11$

$708 \mathrm{~mm} / \mathrm{yr}$ of $\sim \mathrm{NS}$ shortening west of the Angmong junction (Fig. 13d). This may be further 709 decomposed into $\sim 4.5-7.5 \mathrm{~mm} / \mathrm{yr}$ of dextral motion along the northern Karakorum fault and $\sim 5.5$ $710 \mathrm{~mm} / \mathrm{yr}$ of shortening across the high Karakorum range (Fig. 13e). Note that a faster dextral slip

711 rate along the central Karakorum fault is consistent with very short-term InSAR geodetic 712 observation (Wang and Wright, 2012). Most importantly, the kinematics of the latter, Angmong 713 junction, would thus account for the rise of the second highest mountain range in Asia after the 714 central Himalayas. The dextral rate decrease and the glaciated, high topography past that 715 junction would explain why the active Karakorum fault was mistakenly inferred by some (e.g., 716 Robinson, 2009) to terminate north of $\sim 34^{\circ} \mathrm{N}$.

717 Detailed field studies are still lacking in the region separating the Himalayas from the Tarim 718 basin. Active faults that might bound the steep SW and NE faces of the West Kunlun and 719 Karakorum ranges (dark blue patches in Fig. 13a), contributing to the deformation budget across 720 the plateau, remain unexplored. This notwithstanding, however, a pattern of regional 721 deformation dominated by block faulting seems to be inescapable. Triple junction-governed slip- 
722 partitioning, similar to that long-successful in plate tectonics (e.g., McKenzie and Morgan,

723 1969), appears to account best for changes in slip rates at the merging points between the central

724 ATF, KXF and LGCF, southern and northern Karakorum and Longmu Co faults, and between

725 the Qira fault, Mingfeng-Cherchen and Mazar Tagh thrusts (Fig. 13a). Likewise, the fact that the

726 highest mountains in western Tibet abruptly terminate near two of these junctions is best

727 explained by triple junction kinematics. Stronger crustal shortening, accounting for both the

728 maximum elevations of the Karakorum range and northwestward right-lateral slip decrease along

729 the eponymous fault (Chevalier et al., 2016), may just be interpreted as a simple consequence of

730 such kinematics. While the current, local geodetic dataset remains insufficient, both space- and

731 time-wise, to fully corroborate block tectonics, the main amplitude and directional changes of

732 extant GPS vectors (a total of $\sim 13^{\circ}$ anticlockwise, top right inset in Fig. 13a, Wang and Shen,

733 2020) between the Himalaya and the Tarim tend to coincide with the positions of the main active

734 faults. That several of the largest faults follow ancient, likely weak, crustal/lithospheric divides

735 between the main terranes of the Tibetan collage (e.g., Oytag, Jinsha and Bangong sutures, Matte

736 et al., 1996; Wittlinger et al., 2004), mechanically justifies the observed behavior. Crucially,

737 while complex, the late Quaternary kinematics across western Tibet strongly support simple

738 block tectonics rather than broadly diffuse deformation (Peltzer and Tapponnier, 1988; Meyer et

739 al., 1998; Tapponnier et al., 2001; Loveless and Meade, 2011).

\section{Conclusion}

New slip rate measurements along the Karakax and Longmu Co faults, westernmost

743 branches of the Altyn Tagh fault, help understand broad-scale block kinematics across the

744 western tip of the Tibetan Plateau, between the Ganges plain and the Tarim basin. Over the last 
$745 \sim 210 \mathrm{ka}$ (age of the oldest alluvial surface dated thus far in northwestern Tibet), and possibly

746 since $\sim 24 \mathrm{Ma}$, the slip rate along the Karakax fault seems to have remained constant, between 2

747 and $3 \mathrm{~mm} / \mathrm{yr}$, as recently shown by Peltzer et al. (2020) since $\sim 115 \mathrm{ka}$. Since the beginning of the

748 Holocene, great earthquakes (M 7.6) appear to have ruptured at least $\sim 150 \mathrm{~km}$ of the fault with

749 fairly regular, if long ( $2500 \pm 500$ years) return times, and with characteristic co-seismic slip

750 amounts on order of $6 \mathrm{~m}$ - as was the case for the last, likely $1882 \mathrm{AD}$ event - for four such

751 events. These conclusions are based on the combination of high-resolution digital elevation

752 surveys and dating of alluvial fan and terrace offsets at Taersa in the Karakax valley, and of lake

753 shoreline and glacial valley offsets by the Longmu Co fault south of Sumxi Lake. Along the

754 Karakax fault, the well-known, $\sim 80 \mathrm{~km}$ offset of the Karakax river may have accrued since uplift

755 of the West Kunlun range started in the early Miocene ( $\sim 24 \mathrm{Ma})$. The sum of the slip rates on the

756 Longmu Co fault ( $\sim 6 \mathrm{~mm} / \mathrm{yr})$ with those on the Karakax fault $(\sim 2-3 \mathrm{~mm} / \mathrm{yr})$ and on the active

757 thrusts $(2 \mathrm{x} \sim 2 \mathrm{~mm} / \mathrm{yr}=\sim 4 \mathrm{~mm} / \mathrm{yr})$ along the Tarim foreland of the Kunlun, yields a total of $\geq 12$

$758 \mathrm{~mm} / \mathrm{yr}$ along the central Altyn Tagh fault, between central Tibet and the Tarim, in keeping with

759 the modern InSAR rate ( $\geq 10.5 \mathrm{~mm} / \mathrm{yr})$ obtained by Daout et al. (2018). To a first order, at the

760 scale of the entire western plateau, block tectonics and triple junction kinematics appear to

761 account for the recent and late Tertiary continental deformation, even though the seven blocks

762 involved, particularly the Tianshuihai block, may not be torsionally rigid. Specifically, the

763 junction between the conjugate Longmu Co and Karakorum strike-slip faults may be key to

764 explain the rise and abrupt southern termination of the high Karakorum range, second highest in

765 the world. Our results bridge the gaps between present and long-term geological history, and

766 between broad-scale geodesy and local field evidence. 


\section{Acknowledgments and Data}

769 This work was supported by the 2nd Tibetan Plateau Scientific Expedition of the Ministry of

770 Science and Technology of China (2019QZKK0901), the National Natural Science Foundation

771 of China (41672211, 41941016), the China Geological Survey (DD20190059), the Basic

772 Research Funds of the Institute of Geology, Chinese Academy of Geological Sciences

773 (JYYWF201810), and Key Special Project for Introduced Talents Team of Southern Marine

774 Science and Engineering Guangdong Laboratory (Guangzhou) (GML2019ZD0201). The first

775 exploratory 1989 field trip was funded by INSU-CNRS, the French Ministry of Research and

776 Higher Education and the Chinese Academy of Geological Sciences (CAGS). The 1995 field

777 work was supported by a NASA SIC-C investigation. LLNL's participation in the 1995 sampling

778 trip as well as cosmogenic dating of those 1995 samples were supported by the Laboratory

779 Directed Research Project (01-ERI-009) at Lawrence Livermore National Laboratory operating

780 under the auspices of the US Department of Energy by Lawrence Livermore National Laboratory

781 under Contract DE-AC52-07NA27344. Dating at the ASTER AMS French national facility

782 (CEREGE, Aix-en-Provence) was supported by the INSU-CNRS, the French Ministry of

783 Research and Higher Education, IRD, and CEA. We thank J.P. Avouac for his participation in

784 the 1989 field expedition, and M. Bai for his help with the LiDAR processing and Matlab run.

785 We thank the Editor, Associate Editor, and two anonymous reviewers for their constructive

786 comments. Ages and digital elevation surveys (LiDAR and UAV) data are available at

787 https://zenodo.org/record/5115549\#.YPjRpC0RrjA. 
Amidon, W. H., Bookhagen, B., Avouac, J. P., Smith, T., \& Rood, D. (2013), Late Pleistocene glacial advances in the western Tibet interior. Earth and Planetary Science Letters, 381, 210 221. https://doi: 10.1016/j.eps1.2013.08.041.

Armijo, R., Tapponnier, P., \& Han, T. (1989), Late Cenozoic right-lateral strike-slip faulting in southern Tibet. Journal of Geophysical Research Solid Earth, 94(B3), 2787-2838. https://doi.org/10.1029/JB094iB03p02787.

Avouac, J. P., \& Peltzer, G. (1993), Active tectonics in southern Xinjiang, China: Analysis of terrace riser and normal fault scarp degradation along the Hotan-Qira fault system. Journal of Geophysical Research Solid Earth, 98(B12),773-807. https://doi.org/10.1029/93JB02172.

Avouac, J. P., \& Tapponnier, P. (1993), Kinematic model of active deformation in central Asia.

800 Geophysical Research Letters, 20(10), 895-898. https://doi.org/10.1029/93GL00128.

801 Avouac, J. P., Dobremez, J. F., \& Bourjot, L. (1996), Palaeoclimatic interpretation of a 802 topographic profile across middle Holocene regressive shorelines of Longmu Co (Western 803 Tibet). Palaeogeography Palaeoclimatology Palaeoecology, 120, 93-104.

$804 \quad$ https://doi.org/10.1016/0031-0182(96)88700-1.

805 Balco, G., Stone, J. O., Lifton, N. A., \& Dunai, T. J. (2008), A complete and easily accessible means of calculating surface exposure ages or erosion rates from ${ }^{10} \mathrm{Be}$ and ${ }^{26} \mathrm{Al}$

809 Bevington, P.R., \& Robinson, D.K. (2002), Data Reduction and Error Analysis for the Physical Sciences, 336 pp., McGraw-Hill, New York.

811 Blisniuk, P. M., \& Sharp, W. D. (2003). Rates of late Quaternary normal faulting in central Tibet from 
814 Brown, E. T., Bendick, R., Bourlès, D. L., Gaur, V., \& Yiou, F. (2003), Early Holocene climate recorded 815 in geomorphological features in Western Tibet. Palaeogeography Palaeoclimatology

816 Palaeoecology, 199(1), 141-151. https://doi.org/10.1016/S0031-0182(03)00501-7.

817 Cao, K., Wang, G. C., Bernet, M., van der Beek, P., \& Zhang, K. X. (2015), Exhumation history 818 of the West Kunlun Mountains, northwestern Tibet: Evidence for a long-lived, rejuvenated 819 orogen. Earth and Planetary Science Letters, 432, 391-403. Doi:10.1016/j.eps1.2015.10.033.

820 Chen, X. (1988), Xinjiang earthquake catalogue ( $\mathrm{ms} \geq 4.7)$ from 1600 to 1987. Inland

$821 \quad$ Earthquakes, 3, 320-340. https://doi:10.16256/j.issn.1001-8956.1988.03.016

822 Chevalier, M. L., Ryerson, F. J., Tapponnier, P., Finkel, R. C., Van der Woerd, J., Li, H., \& Liu, 823 Q. (2005), Slip-rate measurements on the Karakorum Fault may imply secular variations in 824 fault motion. Science, 307(5708), 411-414. https://doi:10.1126/science.1105466.

825 Chevalier, M. L., Van der Woerd, J., Tapponnier, P., Li, H., Ryerson, F. J., \& Finkel, R. C.

826 (2016), Late Quaternary slip-rate along the central Bangong-Chaxikang segment of the 827 Karakorum fault, western Tibet. Geological Society of America Bulletin, 128(1-2), 284-314. 828 https://doi:10.1130/b31269.1.

829 Chevalier, M. L., Pan, J., Li, H., Sun, Z., Liu, D., Pei, J., et al. (2017). First tectonic-

830 geomorphology study along the Longmu-Gozha Co fault system, Western Tibet. Gondwana $831 \quad$ Research, 41, 411-424. https://doi:10.1016/j.gr.2015.03.008.

832 Cowgill, E. (2007), Impact of riser reconstructions on estimation of secular variation in rates of 833 strike-slip faulting: Revisiting the Cherchen River site along the Altyn Tagh Fault, NW 834 China. Earth and Planetary Science Letters, 254(3-4), 239-255.

835 doi:10.1016/j.epsl.2006.09.015. 
836 Daëron, M., Klinger, Y., Tapponnier, P., Elias, A., Jacques, E., \& Sursock, A. (2007), 12,000-

837 year-long record of 10 to 13 paleoearthquakes on the Yammouneh fault, Levant fault system,

838 Lebanon. Bulletin of the Seismological Society of America, 97(3), 749-771.

839 https://doi:10.1785/0120060106.

840 Daout, S., Doin, M. P., Peltzer, G., Lasserre, C., Socquet, A., Volat, M., \& Sudhaus, H. (2018),

841 Strain partitioning and present day fault kinematics in NW Tibet from Envisat SAR

842 interferometry. Journal of Geophysical Research, 123(3), 2462-2483.

843 https://doi:10.1002/2017jb015020.

844 DeMets, C., Gordon, R. G., Argus, D., \& Stein, S. (1990), Current plate motions. Geophysical

845 journal international, 101(2), 425-478. https://doi.org/10.1111/j.1365-246X.1990.tb06579.x.

846 Ding, G., Chen, J., Tian, Q., Shen, X., Xing, C., \& Wei, K. (2004), Active faults and magnitudes

847 of left-lateral displacement along the northern margin of the Tibetan Plateau. Tectonophysics,

$848 \quad$ 380(3-4), 243-260. Doi:10.1016/j.tecto.2003.09.022.

849 Farr, T., \& Chadwick, O. (1996). Geomorphic processes and remote sensing signatures of

850 alluvial fans in the Kunlun Mountains, China. Journal of Geophysical Research,

$851 \quad 101(\mathrm{E} 10), 23,091-23,100$.

852 Gasse, F., Téhet, R., Durand, A., Gibert, E., \& Fontes, J. C. (1990), The arid-humid transition in

853 the Sahara and the Sahel during the last deglaciation. Nature, 346(6280), 141-146.

854 Gasse, F., Arnold, M., Fontes, J. C., Fort, M., Gibert, E., Huc, A. et al. (1991), A 13,000-year

855 climate record from western Tibet. Nature, 353(6346), 742-745. https://doi:

$856 \quad$ 10.1016/j.tecto.2003.09.022.

857 Gaudemer, Y., Tapponnier, P., \& Turcotte, D. (1989), River offsets across active strike-slip 858 faults. Annales Tectonicae, 3, 55-76. 
Gold, R. D., Cowgill, E., Arrowsmith, R., Gosse, J., Chen, X., \& Wang, X. (2009). Riser diachroneity, lateral erosion, and uncertainty in rates of strike-slip faulting: A case study from Tuzidun along the Altyn Tagh Fault, NW China. Journal of Geophysical Research, 114(B04401), 1-24. https://doi.org/10.1029/2008JB005913

863

Gold, R. D., Cowgill, E., Arrowsmith, J. R., Chen, X., Sharp, W. D., Cooper, K. M., \& Wang, X.

864 (2011), Faulted terrace risers place new constraints on the late Quaternary slip rate for the central Altyn Tagh fault, northwest Tibet. Geological Society of America Bulletin, 123(5-6), 958-978. https://doi.org/10.1130/B30207.1.

867 Gong, Z., Sun, J., Zhang, Z., Fu, B., \& Jia, Y. (2017), Optical dating of an offset river terrace sequence across the Karakax fault and its implication for the late Quaternary left-lateral slip rate. Journal of Asian Earth Sciences, 147, 415-423. https://doi.org/10.1016/j.jseaes.2017.07.013.

Guilbaud, C., Simoes, M., Barrier, L., Laborde, A., Van der Woerd, J., Li, H. et al. (2017), Kinematics of active deformation across the Western Kunlun mountain range (Xinjiang, China) and potential seismic hazards within the southern Tarim Basin. Journal of Geophysical Research, 122(12), 10,398-426. Doi:10.1002/2017JB014069.

Hetzel, R., Niedermann, S., Tao, M.X., Kubik, P.W., Ivy-Ochs, S., Gao, B., Strecker, M.R., (2002), Low slip rates and long-term preservation of geomorphic features in Central Asia. Nature, 417, 428-432.

Hidy, A. J., Gosse, J. C., Pederson, J. L., Mattern, J. P., \& Finkel, R. C. (2010), A geologically constrained Monte Carlo approach to modeling exposure ages from profiles of cosmogenic nuclides: An example from Lees Ferry, Arizona. Geochemistry, Geophysics, Geosystems, 11(9) ,1-18. https://doi:10.1029/2010gc003084. 
882 Kohl, C. P., \& Nishiizumi, K. (1992), Chemical isolation of quartz for measurement of in-situ 883 produced cosmogenic nuclides. Geochimica et Cosmochimica Acta, 56(9), 3583-3587.

884 https://doi.org/10.1016/0016-7037(92)90401-4.

885 Laborde, A., Barrier, L., Simoes, M., Li, H., Coudroy, T., Van der Woerd, J., \& Tapponnier, P. 886 (2019), Cenozoic deformation of the Tarim Basin and surrounding ranges (Xinjiang, China):

887 A regional overview. Earth Science Reviews, 197, 102891.

$888 \quad$ https://doi:10.1016/j.earscirev.2019.102891.

889 Lal, D. (1991), Cosmic ray labeling of erosion surfaces: in situ nuclide production rates and 890 erosion models. Earth and Planetary Science Letters, 104(2-4), 424-439.

891 https://doi:10.1016/0012-821x(91)90220-c.

892 Li, H., Van Der Woerd, J., Tapponnier, P., Yann, K., Qi, X., Yang, J., \& Zhu, Y. (2005), Slip 893 rate on the Kunlun fault at Hongshui Gou, and recurrence time of great events comparable to 894 the 14/11/2001, Mw7.9 Kokoxili earthquake. Earth and Planetary Science Letters, 237(1-2), $895 \quad$ 285-299. https://doi.org/10.1016/j.epsl.2005.05.041.

896 Li, H., Van Der Woerd, J., Sun, Z., Si, J., Tapponnier, P., Pan, J. et al. (2012), Co-seismic and 897 cumulative offsets of the recent earthquakes along the Karakax left-lateral strike-slip fault in 898 western Tibet. Gondwana Research, 21(1), 64-87. https://doi:10.1016/j.gr.2011.07.025.

899 Li, H., Pan, J., Lin, A., Sun, Z., Liu, D., Zhang, J. et al. (2016), Coseismic Surface Ruptures

900 Associated with the 2014Mw 6.9 Yutian Earthquake on the Altyn Tagh Fault, Tibetan 901 Plateau. Bulletin of the Seismological Society of America, 106, 595-608.

902 https://doi:10.1785/0120150136. 
903 Lifton, N., Sato, T., \& Dunai, T. J. (2014), Scaling in situ cosmogenic nuclide production rates

904 using analytical approximations to atmospheric cosmic-ray fluxes. Earth and Planetary

905 Science Letters, 386, 149-160. https://doi:10.1016/j.eps1.2013.10.052.

906 Lisiecki, L. E., \& Raymo, M. E. (2005), A Pliocene Pleistocene stack of 57 globally distributed

907 benthic $\delta^{18} \mathrm{O}$ records. Paleoceanography, 20(1), 1-17. https://doi:10.1029/2004pa001071.

908 Liu, Q. (1993), Paleoclimat et contraintes chronologiques sur les mouvements récents dans

909 l'Ouest du Tibet: failles du Karakorum et de Longmu Co-Gozha Co, lacs en pull-apart de

910 Longmu Co et de Sumxi Co, (Doctoral dissertation). Université de Paris VII.

911 Loveless, J. P., \& Meade, B. J. (2011), Partitioning of localized and diffuse deformation in the

912 Tibetan Plateau from joint inversions of geologic and geodetic observations. Earth and

913 Planetary Science Letters, 303(1-2), 11-24. https://doi: 10.1016/j.eps1.2010.12.014.

914 Lu, R., Xu, X., He, D., Liu, B., Tan, X., \& Wang, X. (2016), Coseismic and blind fault of the

915 2015 Pishan Mw 6.5 earthquake: Implications for the sedimentary tectonic framework of

916 the western Kunlun Mountains, northern Tibetan Plateau. Tectonics, 35(4), 956-964.

917 https://doi:10.1002/2015tc004053.

918 Lyon Caen, H., \& Molnar, P. (1984), Gravity anomalies and the structure of western Tibet and

919 the southern Tarim Basin. Geophysical Research Letters, 11(12), 1251-1254.

920 https://doi.org/10.1029/GL011i012p01251.

921 Ma, X. (Eds.) (1989), Seismotectonic map of xinjiang, lithospheric dynamics atlas of china.

922 China cartographic publishing house.

923 Ma, S., Yao, Z., \& Ji, C. (1997), The Focal Mechanism Solution for March 19, 1996 M s 6.9

924 Earthquake in XinJiang Jia-Shi Region and Related Problems. Acta Geophysica Sinica, 40, $925 \quad 789-800$. 
926 Matte, P., Tapponnier, P., Arnaud, N., Bourjot, L., Avouac, J., Vidal, P. et al. (1996), Tectonics

927 of Western Tibet, between the Tarim and the Indus. Earth and Planetary Science Letters,

928 142(3-4), 311-330. https://doi:10.1016/0012821x(96)00086-6.

929 McKenzie, D.P., \& Morgan, W.J. (1969), Evolution of triple junctions. Nature, 224, 125-133, 930 doi:10.1038/224125a0.

931 Mériaux, A. S., Ryerson, F., Tapponnier, P., Van der Woerd, J., Finkel, R., Xu, X., Xu, Z., \&

932 Caffee, M. (2004), Rapid slip along the central Altyn Tagh Fault: morphochronologic

933 evidence from Cherchen He and Sulamu Tagh. Journal of Geophysical Research, 109(B6),

934 1-23. Doi:10.1029/2003jb002558.

935 Mériaux, A. S., Tapponnier, P., Ryerson, F. J., Xu, X., King, G., van der Woerd, J., et al. (2005).

936 The Aksay segment of the northern Altyn Tagh fault: Tectonic geomorphology,

937 landscape evolution, and Holocene slip rate. Journal of Geophysical Research, 110,

938 B04404. https://doi.org/10.1029/2004JB003210

939 Mériaux, A. S., Van der Woerd, J., Tapponnier, P., Ryerson, F., Finkel, R., Lasserre, C., \& Xu,

940 X. (2012), The Pingding segment of the Altyn Tagh Fault $\left(91^{\circ} \mathrm{E}\right)$ : Holocene slip rate

941 determination from cosmogenic radionuclide dating of offset fluvial terraces. Journal of

942 Geophysical Research, 117(B9). https://doi:10.1029/2012jb009289.

943 Métivier, F., Gaudemer, Y., Tapponnier, P., \& Klein, M. (1999), Mass accumulation rates in

944 Asia during the Cenozoic. Geophysical Journal International, 137(2), 280-318.

945 https://doi.org/10.1046/j.1365-246X.1999.00802.x.

946 Meyer, B., Tapponnier, P., Gaudemer, Y., Peltzer, G., Guo, S. \& Chen, Z. (1996), Rate of left-

947 lateral movement along the easternmost segment of the Altyn Tagh fault, east of 96"E

948 (China). Geophysical Journal International, 124, 29-44. 
949 Meyer, B., Tapponnier, P., Bourjot, L., Metivier, F., Gaudemer, Y., Peltzer, G. et al. (1998),

950 Crustal thickening in Gansu-Qinghai, lithospheric mantle subduction, and oblique, strike-slip

951 controlled growth of the Tibet plateau. Geophysical Journal International, 135(1), 1-47.

952 https://doi.org/10.1046/j.1365-246X.1998.00567.x.

953 Molnar, P., \& Lyon-Caen, H. (1989), Fault plane solutions of earthquakes and active tectonics of

954 the Tibetan Plateau and its margins. Geophysical Journal International, 99(1), 123-153.

955 https://doi.org/10.1111/j.1365-246X.1989.tb02020.x.

956 Molnar, P., Burchfiel, B. C., Liang, K., \& Zhao, Z. (1987), Geomorphic evidence for active

957 faulting in the Altyn Tagh and northern Tibet and qualitative estimates of its contribution to

958 the convergence of India and Eurasia. Geology, 15(3), 249-253.

959 https://doi.org/10.1130/0091-7613(1987)15.

960 Nikonov, A. A. (1975), Migration of strong earthquakes along the greatest zones of faults in

961 Central Asia. Doklady Akademii Nauk, 225(2), 306-309.

962 Pan, J., Li, H., Van Der Woerd, J., Sun, Z., Si, J., Pei, J. et al. (2015), The first quantitative slip-

963 rate estimated along the Ashikule Fault at the western segment of the Altyn Tagh Fault

964 System. Acta Geologica Sinica (English Edition), 89(6), 2088-2089.

965 https://doi:10.1111/1755-6724.12621.

966 Peltzer, G., \& Tapponnier, P. (1988), Formation and evolution of strike-slip faults, rifts, and

967 basins during the India-Asia collision; an experimental approach. Journal of Geophysical

$968 \quad$ Research, 93, 15,085-15,117.

969 Peltzer, G., Tapponnier, P., \& Armijo, R. (1989), Magnitude of Late Quaternary Left-Lateral

970 Displacements Along the North Edge of Tibet. Science, 246(4935), 1285-1289.

$971 \quad$ https://doi:10.1126/science.246.4935.1285. 
972 Peltzer, G., Brown, N. D., Mériaux, A. S., van der Woerd, J., Rhodes, E. J., Finkel, R. C. et al.

973 (2020), Stable rate of slip along the Karakax Section of the Altyn Tagh Fault from

974 observation of interglacial and postglacial offset morphology and surface dating. Journal of

975 Geophysical Research: Solid Earth, 125(5). https://doi:10.1029/2019jb018893.

976 Raterman, N. S., Cowgill, E., \& Lin, D. (2007), Variable structural style along the Karakoram

977 fault explained using triple-junction analysis of intersecting faults. Geosphere, 3(2), 71-85.

978 https://doi:10.1130/ges00067.1.

979 Robinson, A. C. (2009), Evidence against Quaternary slip on the northern Karakorum Fault

980 suggests kinematic reorganization at the western end of the Himalayan-Tibetan orogen.

$981 \quad$ Earth and Planetary Science Letters, 286(1-2), 158-170.

982 https://doi:10.1016/j.epsl.2009.06.025.

983 Ryerson, F., Peltzer, G., Tapponnier, P., Finkel, R., Mériaux, A., Van der Woerd, J., \& Caffee,

984 M. (1999), Active slip-rates on the Altyn Tagh Fault-Karakax Valley segment: Constraints

985 from surface exposure dating. Eos Trans. $A G U, 80(46), 1008$.

986 Ryerson, F.J., Tapponnier, P., Finkel, R.C., Mériaux, A.S., Van der Woerd, J., Lasserre, C.,

987 Chevalier, M.L., Xiwei, X., Li, H., \& King, G.C.P. (2006), Applications of

988 morphochronology to the active tectonics of Tibet, in Siame, L.L., Bourles, D.L., and

989 Brown, E.T. ,eds., Application of Cosmogenic Nuclides to the Study of Earth Surface

990 Processes: The Practice and the Potential. Geological Society of America Special Paper

$991 \quad$ 415, 61-86, doi: $10.1130 / 2006.2415(05)$

992 Seismological bureau of Xinjiang Uygur autonomous region (1997), Instruction of Xinjiang

993 Uygur autonomous region seismotectonic map (1:2000000), Xinjiang. 
994 Shen, Z. K., Wang, M., Li, Y., Jackson, D. D., Yin, A., Dong, D., \& Fang, P. (2001), Crustal 995 deformation along the Altyn Tagh fault system, western China, from GPS. Journal of 996 Geophysical Research: Solid Earth, 106(B12), 30607-30621.

997 https://doi:10.1029/2001jb000349.

998 Sobel, E. R., \& Dumitru, T. A. (1997), Thrusting and exhumation around the margins of the 999 western Tarim basin during the India-Asia collision. Journal of Geophysical Research, 1000 102(B3), 5043-5063. https://doi.org/10.1029/96JB03267.

1001 Stewart, N., Gaudemer, Y., Manighetti, I., Serreau, L., Vincendeau, A., Dominguez, S., ... 1002 Malavieille, J. (2018), “3D_Fault_Offsets,” a Matlab code to automatically measure 1003 1004 1005 lateral and vertical fault offsets in topographic data: Application to San Andreas, Owens Valley, and Hope faults. Journal of Geophysical Research, 123, 815-835. https://doi.org/10.1002/2017JB014863

1006 Stone, J.O. (2000), Air pressure and cosmogenic isotope production. Journal of Geophysical 1007 Research, 105(B10), 23753-23759. https://doi:10.1029/2000jb900181.

1008 Tao, Y., Xiong, J., Zhang, H., Chang, H., \& Li, L. (2020), Climate-driven formation of fluvial 1009 terraces across the Tibetan Plateau since 200 kya: A review. Quaternary Science Reviews, 237, 1010 106303. doi: 10.1016/j.quascirev.2020.106303.

1011 Tapponnier, P., \& Molnar, P. (1977), Active faulting and tectonics in China. Journal of 1012 Geophysical Research, 82(20), 2905-2930. https://doi:10.1029/jb082i020p02905.

1013 Tapponnier, P., Xu, Z., Roger, F., Meyer, B., Arnaud, N., Wittlinger, G., \& Yang, J. (2001), 1014 Oblique stepwise rise and growth of the Tibet Plateau. Science, 294(5547), 1671-1677. 1015 https://doi:10.1126.science.105978. 
1016 Van Buer, N. J., Jagoutz, O., Upadhyay, R., \& Guillong, M. (2015), Mid-crustal detachment 1017 beneath western Tibet exhumed where conjugate Karakoram and Longmu-Gozha Co faults 1018 intersect. Earth and Planetary Science Letters, 413, 144-157.

1019 https://doi:10.1016/j.epsl.2014.12.053.

1020 Van Der Woerd, J. V., Tapponnier, P., J. Ryerson, F., Mériaux, A.-S., Meyer, B., Gaudemer, Y., 1021 Finkel, R. C., Caffee, M. W., Guoguan, Z., \& Zhiqin, X. (2002), Uniform postglacial slip1022 rate along the central $600 \mathrm{~km}$ of the Kunlun Fault (Tibet), from 26Al, 10Be, and 14C dating 1023 of riser offsets, and climatic origin of the regional morphology. Geophysical Journal 1024 International, 148(3), 356-388. https://doi:10.1046/j.1365-246x.2002.01556.x.

1025 Wang, H., \& Wright, T. (2012), Satellite geodetic imaging reveals internal deformation of 1026 western Tibet. Geophysical Research Letters, 39(7). https://doi:10.1029/2012g1051222.

1027 Wang, M., \& Shen, Z. K. (2020), Present day crustal deformation of continental China derived 1028 from GPS and its tectonic implications. Journal of Geophysical Research, 125(2), 1029 e2019JB018774. https://doi:10.1029/2012g1051222.

1030 Wells, D. L., \& Coppersmith, K. J. (1994), New empirical relationships among magnitude, 1031 rupture length, rupture width, rupture area, and surface displacement. Bulletin of the 1032 seismological Society of America, 84(4), 974-1002.

1033 Wen, Y., Xu, C., Liu, Y., \& Jiang, G. (2016), Deformation and source parameters of the 2015 1034 Mw 6.5 earthquake in Pishan, western China, from Sentinel-1A and ALOS-2 data. Remote 1035 sensing, 8(2), 134. https://doi:10.3390/rs8020134.

1036 Whipple, K. X., \& Tucker, G. E. (1999), Dynamics of the stream power river incision model: 1037 Implications for height limits of mountain ranges, landscape response timescales, and 
1038 research needs. Journal of Geophysical Research, 104(B8), 17661-17674.

1039 https://doi:10.1029/1999jb900120.

1040 Wittlinger, G., Vergne, J., Tapponnier, P., Farra, V., Poupinet, G., Jiang, M., Su, H., Herquel, G., $1041 \&$ Paul, A. (2004), Teleseismic imaging of subducting lithosphere and Moho offsets beneath 1042 western Tibet. Earth and Planetary Science Letters, 221(1-4), 117-130.

1043 Wright, T. J., Parsons, B., England, P. C., \& Fielding, E. J. (2004), InSAR observations of low 1044 slip rates on the major faults of western Tibet. Science, 305(5681), 236-239.

1045 https://doi:10.1126/science.1096388.

1046 Xu, X., Tan, X., Yu, G., Wu, G., Fang, W., Chen, J. et al. (2013), Normal-and oblique-slip of the 10472008 Yutian earthquake: evidence for eastward block motion, northern Tibetan Plateau. $1048 \quad$ Tectonophysics, 584, 152-165. https://doi:10.1016/j.tecto.2012.08.007.

1049 Yao, T., Jiao, K., Tian, L., Yang, Z., Shi, W., \& Thompson, L.G. (1996), Climatic variations 1050 since the Little Ice Age recorded in the Guliya Ice Core. Science in China, 39, 6.

1051 Yang, Y., Li, Q., Ai, M., Shi, Z., Yan, J. (1991), Some queries for the Hotan earthquake 1882 1052 and the Yeeryang earthquake 1889 in Xinjiang. Northeastern Seismological Research, 7(1), 1053 87-93. https://doi: 10.13693/j.cnki.cn21-1573.1991.01.014.

1054 Zechar, J. D., \& Frankel, K. L. (2009), Incorporating and reporting uncertainties in fault slip 1055 rates. Journal of Geophysical Research, 114, B12407.

1056 https://doi.org/10.1029/2009JB006325. 